\title{
GENDER EQUALITY \\ AND THE MATH GENDER GAP
}

2020

BANCODEESPAÑA

Eurosistema

Documentos de Trabajo

N. ${ }^{\circ} 2031$

Brindusa Anghel, Núria Rodríguez-Planas

and Anna Sanz-de-Galdeano 
GENDER EQUALITY AND THE MATH GENDER GAP $\left.{ }^{*}\right)$

\section{Brindusa Anghel}

BANCO DE ESPAÑA

\section{Núria Rodríguez-Planas}

CITY UNIVERSITY OF NEW YORK (CUNY), QUEENS COLLEGE

\section{Anna Sanz-de-Galdeano}

UNIVERSITY OF ALICANTE AND IZA

${ }^{(*)}$ We are grateful to Jorge Agüero, Pedro Albarrán, Dimitris Christelis, Andrew Oswald, Anastasia Terskaya, seminar participants at the Bank of Spain, and participants to the 32nd Annual Conference of the European Society for Population Economics in Antwerp (Belgium) for helpful comments on earlier drafts. Sanz-de-Galdeano is also affiliated with CRES-UPF. She acknowledges financial support from the Spanish Ministry of Economy and Competitiveness ECO2017-87069-P, and from PROMETEO/2019/037. Authors' contact: Brindusa Anghel, Banco de España, Calle Alcalá, 48, Madrid 28014, Spain. Email: brindusa.anghel@bde.es. Núria Rodríguez-Planas, Queens College - CUNY, Economics Department, Powdermaker Hall, 65-30 Kissena Blvd., Queens, New York 11367, USA. Email: nuria.rodriguezplanas@qc.cuny.edu. Anna Sanz-de-Galdeano, FAE, Universidad de Alicante, Carretera de San Vicente s/n, 03080 San Vicente - Alicante, Spain. Email: anna. sanzdegaldeano@gmail.com. 
The Working Paper Series seeks to disseminate original research in economics and finance. All papers have been anonymously refereed. By publishing these papers, the Banco de España aims to contribute to economic analysis and, in particular, to knowledge of the Spanish economy and its international environment.

The opinions and analyses in the Working Paper Series are the responsibility of the authors and, therefore, do not necessarily coincide with those of the Banco de España or the Eurosystem.

The Banco de España disseminates its main reports and most of its publications via the Internet at the following website: http://www.bde.es.

Reproduction for educational and non-commercial purposes is permitted provided that the source is acknowledged.

(C) BANCO DE ESPAÑA, Madrid, 2020

ISSN: 1579-8666 (on line) 


\section{Abstract}

In their seminal article, Guiso et al. (2008) uncover a positive relationship between several measures of gender equality and the math gender gap (which tends to favor boys) by exploiting cross-sectional variation in PISA test scores from 39 countries - the majority of which belong to the OECD - at a given year (2003). Using five waves of PISA data spanning the period 2003-2015 and exploiting variation both across - and within - countries, we find that the positive association between the female-male gender gap in math test scores and several measures of gender equality vanishes in OECD countries once we account for country fixed effects. Interestingly, our analysis also uncovers a positive and statistically significant association between the math gender gap and several gender equality indicators for countries in the bottom quartile of per capita GDP. This association is robust to controlling for country-level time-invariant unobserved heterogeneity.

Keywords: gender gap in math test scores, gender equality.

JEL classification: I, Z1. 


\section{Resumen}

En su influyente artículo, Guiso et al. (2008) descubrieron una relación positiva entre distintas medidas de igualdad de género y la brecha de género en matemáticas (que tiende a favorecer a los niños), explotando la variación de datos transversales de las puntuaciones en las pruebas de PISA en 39 países - la mayoría, pertenecientes a la OCDE- en 2003. Utilizando cinco olas de los datos de PISA a lo largo del período 2003-2015 y explotando la variación tanto entre los países como dentro de ellos, en este artículo encontramos que la relación positiva entre la brecha de género en las puntuaciones en matemáticas y algunas medidas de igualdad de género desaparece en los países de la OCDE cuando se tienen en cuenta los efectos fijos de los países. Por otra parte, nuestro análisis también evidencia una relación positiva y estadísticamente significativa entre la brecha de género en matemáticas y algunos indicadores de igualdad de género para los países que se sitúan en el cuartil más bajo según el PIB per cápita. Esta relación se mantiene cuando se tiene en cuenta la heterogeneidad no observada, invariante en el tiempo, a nivel de país.

Palabras clave: brecha de género en las puntuaciones en matemáticas, igualdad de género.

Códigos JEL: I, Z1 


\section{INTRODUCTION}

Understanding whether more gender equal societies narrow the gender gap in math, which tends to favor boys, ${ }^{1}$ is a highly policy relevant question that many researchers have investigated. ${ }^{2}$ In their seminal article, Guiso et al. (2008) uncover a positive relationship between several measures of gender equality and the math gender gap between high-school girls and boys. Exploiting crosssectional variation in the Program for International Student Assessment (hereafter PISA) test scores from 39 countries - the majority of which belong to the OECD - at a given year (2003), the authors find that girls' performance in math tests is closer to that of boys (or even better) in those countries where social and economic conditions are relatively more favorable to women.

We revisit and expand their findings by taking advantage of the current availability of more waves of PISA data spanning the period 2003-2015. This allows us to exploit variation both across- and within-countries in order to shed further light on the association between gender equality and the math gender gap. In particular, we investigate whether this association is still relevant once unobserved time invariant heterogeneity is accounted for, and we analyze whether it is heterogeneous across different levels of development.

Our paper also speaks to a related literature that focuses on the role played by gender social norms or cultural attitudes towards gender. Studies focusing on the impact of culture have often relied on the epidemiological approach. This approach aims at isolating the effects of culture (both its permanent and its non permanent components) from the effects of formal institutional factors on different outcomes by comparing $2^{\text {nd }}$ generation immigrants born in a given country (as they share the same formal institutions) with different ancestries. ${ }^{3}$ In the context of the math gender gap, Nollenberger, Rodríguez-Planas and Sevilla (2016) find that greater gender equality in secondgeneration immigrants' countries of ancestry decreases the math gender gap in their host countries (where they were born and live), while Rodríguez-Planas and Nollenberger (2018) show that this finding expands to other subjects.

While our paper is related to this literature, our goal is not to isolate the effects of gender social norms or culture/informal institutions involving gender. The gender equality indicators used in Guiso et al. (2008) and in this paper are likely the combined result of several policy, socioeconomic, and cultural variables. Hence, they should not be interpreted as reflecting culture alone. Instead, we focus on the relationship between gender inequalities and the math gender gap. We investigate whether this association is still relevant once country-specific time-invariant heterogeneity -which may well include, for instance, the permanent component of culture- is accounted for, and we study whether it varies across different levels of economic development.

We find that, once we control for time-invariant unobserved country heterogeneity, the positive and significant association between different indicators of gender equality and the relative performance of girls in mathematics vanishes in both Guiso et al. (2008) original sample (which

\footnotetext{
${ }^{1}$ See for instance Guiso et al. (2008), Fryer and Levitt (2010), Bedard and Cho (2010), Ellison and Swanson (2010), Pope and Sydnor (2010), Nollenberger, Rodríguez-Planas and Sevilla (2016), Rodríguez-Planas and Nollenberger (2018).

2 A complementary strand of the literature has instead focused on the relationship between non gender-related inequalities and the math gender gap. See, for instance, Breda, Jouini, and Napp (2018) and the references therein.

${ }^{3}$ Previous studies relying on this approach have looked into the effects of the source-country gender gaps in wages (Antecol, 2001), labor force participation (Antecol, 2000), and smoking (Rodríguez-Planas and Sanz-de-Galdeano, 2019) on the same gaps for immigrants living in the same host country.
} 
consisted mostly of OECD countries), and in the sample of OECD countries surveyed by PISA during the period 2003-2015. Additionally, we show the association between gender equality and the math gender gap varies depending on countries' level of economic development. In particular, we uncover a positive and significant association between the math gender gap and several gender equality indicators in countries in the bottom quartile of the GDP per capita distribution.

The remainder of the paper is organized as follows. Section 2 introduces the data, Section 3 discusses our empirical approach, Section 4 presents the results, and Section 5 discusses some robustness checks. Conclusions follow.

\section{DATA}

\subsection{PISA Data}

Every three years, the Organization for Economic Cooperation and Development (OECD) conducts the PISA, an internationally standardized assessment administered to 15-year olds in schools. PISA's objective is to determine whether students have acquired the human capital needed to function in society near the end of compulsory education. In the case of mathematics, PISA's literacy "is an individual's capacity to formulate, employ and interpret mathematics in a variety of contexts. It includes reasoning mathematically and using mathematical concepts, procedures, facts and tools to describe, explain and predict phenomena. It assists individuals to recognize the role that mathematics plays in the world and to make the well-founded judgments and decisions needed by constructive, engaged and reflective citizens" (OECD 2017b).

While PISA only collected data for 39 countries in 2003, by 201573 countries spanning all continents had conducted the PISA assessment (Appendix Table A.1). Note that our benchmark analyses will be based on students in the upper half of each country socioeconomic status distribution as in Guiso et al. (2008). ${ }^{4}$ The reason for this is to avoid attrition bias due to potential differential drop-out rates between genders in different countries. Our results, however, are robust to including all students in the estimations, as we will later show.

According to PISA data, over the 2003-2015 period, non-OECD male and female students underperform their OECD counterparts in math by a similar amount: 80 points for males and 78.5 points for females. As for the average gender gap, girls underperform boys in math test scores by 9.9 score points in OECD countries and 3.7 score points in non-OECD countries (see Table 1). ${ }^{5}$

The math gender gap markedly varies both across OECD and non-OECD countries as shown in Appendix Table A.1, and in Figures 1 and 2, becoming negligible in some countries (such as Sweden or Indonesia) while being reversed in others (such as, for instance, Iceland and Malaysia in several years).

\footnotetext{
${ }^{4}$ The PISA dataset collects an indicator called Economic, Social and Cultural Status (ESCS) that measures students' socio-economic status using both parental education, parental occupation, and home possessions. In each country, we computed the $50^{\text {th }}$ percentile of ESCS (taking into account the students' final weights) and dropped all the observations below that threshold for our benchmark analyses.

${ }^{5}$ Because PISA offers five alternative estimates (known as plausible values) of students' ability in each subject, the procedure used to estimate test scores involves calculating the required statistic five times, one for each plausible value (see the OECD recommendations in OECD (2017a). Hence, we calculated the math gender gap in test scores in each country by running a linear regression of each of the plausible values on a constant and a female dummy variable. We then took the average of the five estimated coefficients on the gender dummy in the five regressions as the final gender gap for each particular country.
} 


\begin{tabular}{|c|c|c|c|c|}
\hline & \multicolumn{2}{|c|}{$\begin{array}{l}\text { PISA sample of students above } \\
\text { the median of the ESCS of each } \\
\text { country }\end{array}$} & \multicolumn{2}{|c|}{ PISA sample of all students } \\
\hline & $\begin{array}{c}\text { OECD } \\
\text { countries }\end{array}$ & $\begin{array}{c}\text { Non-OECD } \\
\text { countries }\end{array}$ & $\begin{array}{c}\text { OECD } \\
\text { countries }\end{array}$ & $\begin{array}{c}\text { Non-OECD } \\
\text { countries }\end{array}$ \\
\hline \multicolumn{5}{|l|}{ Panel A } \\
\hline \multicolumn{5}{|l|}{ Average gender gap } \\
\hline \multirow[t]{2}{*}{ Math } & $-9,883$ & $-3,665$ & $-10,202$ & $-4,678$ \\
\hline & $(7,380)$ & $(10,331)$ & $(6,923)$ & $(10,322)$ \\
\hline \multirow[t]{2}{*}{ Reading } & 35,353 & 38,873 & 35,697 & 37,695 \\
\hline & $(9,947)$ & $(13,652)$ & $(10,302)$ & $(14,741)$ \\
\hline \multicolumn{5}{|l|}{ Average PISA score of boys } \\
\hline \multirow[t]{2}{*}{ Math } & 520,475 & 440,212 & 490,885 & 417,972 \\
\hline & $(7,996)$ & $(9,673)$ & $(5,318)$ & $(9,176)$ \\
\hline \multirow[t]{2}{*}{ Reading } & 503,566 & 426,738 & 473,851 & 403,920 \\
\hline & $(4,914)$ & $(10,079)$ & $(5,006)$ & $(11,045)$ \\
\hline \multicolumn{5}{|l|}{ Average PISA score of girls } \\
\hline \multirow[t]{2}{*}{ Math } & 509,061 & 434,051 & 479,284 & 409,065 \\
\hline & $(5,766)$ & $(11,974)$ & $(4,115)$ & $(10,611)$ \\
\hline \multirow[t]{2}{*}{ Reading } & 533,923 & 459,251 & 504,508 & 434,467 \\
\hline & $(5,449)$ & $(10,698)$ & $(5,037)$ & $(9,414)$ \\
\hline \multicolumn{5}{|l|}{ Panel B } \\
\hline \multicolumn{5}{|l|}{ Indices of gender equality } \\
\hline \multirow[t]{2}{*}{ GGI } & 0,722 & 0,677 & 0,722 & 0,677 \\
\hline & $(0,056)$ & $(0,035)$ & $(0,056)$ & $(0,034)$ \\
\hline \multirow[t]{2}{*}{ Economic opportunity index } & 0,673 & 0,632 & 0,673 & 0,632 \\
\hline & $(0,093)$ & $(0,099)$ & $(0,093)$ & $(0,098)$ \\
\hline \multirow[t]{2}{*}{ Political empowerment index } & 0,249 & 0,125 & 0,249 & 0,126 \\
\hline & $(0,153)$ & $(0,070)$ & $(0,153)$ & $(0,070)$ \\
\hline \multirow[t]{2}{*}{ Educ. attainment index } & 0,992 & 0,983 & 0,992 & 0,983 \\
\hline & $(0,018)$ & $(0,019)$ & $(0,018)$ & $(0,019)$ \\
\hline \multirow[t]{2}{*}{ Health and survival index } & 0,976 & 0,969 & 0,976 & 0,969 \\
\hline & $(0,004)$ & $(0,014)$ & $(0,004)$ & $(0,015)$ \\
\hline \multirow[t]{2}{*}{ Ratio FLFP/MLFP (\%) } & 76,648 & 68,956 & 76,648 & 68,856 \\
\hline & $(10,665)$ & $(15,916)$ & $(10,665)$ & $(15,802)$ \\
\hline
\end{tabular}

Notes: Standard deviation in parenthesis

Average PISA score is calculated as the average of all years PISA 2003-2015.

Equally important for our purposes is the fact that the math gender gap is far from constant, that is, it also varies over time within countries, as visual inspection of Figures 1 and 2 also reveals. In addition, Table 2 below shows that within country variation accounts for about $61.5 \%$ and $54.9 \%$ of the total observed variation in the math gender gap in our pooled sample of OECD and nonOECD countries, respectively. 


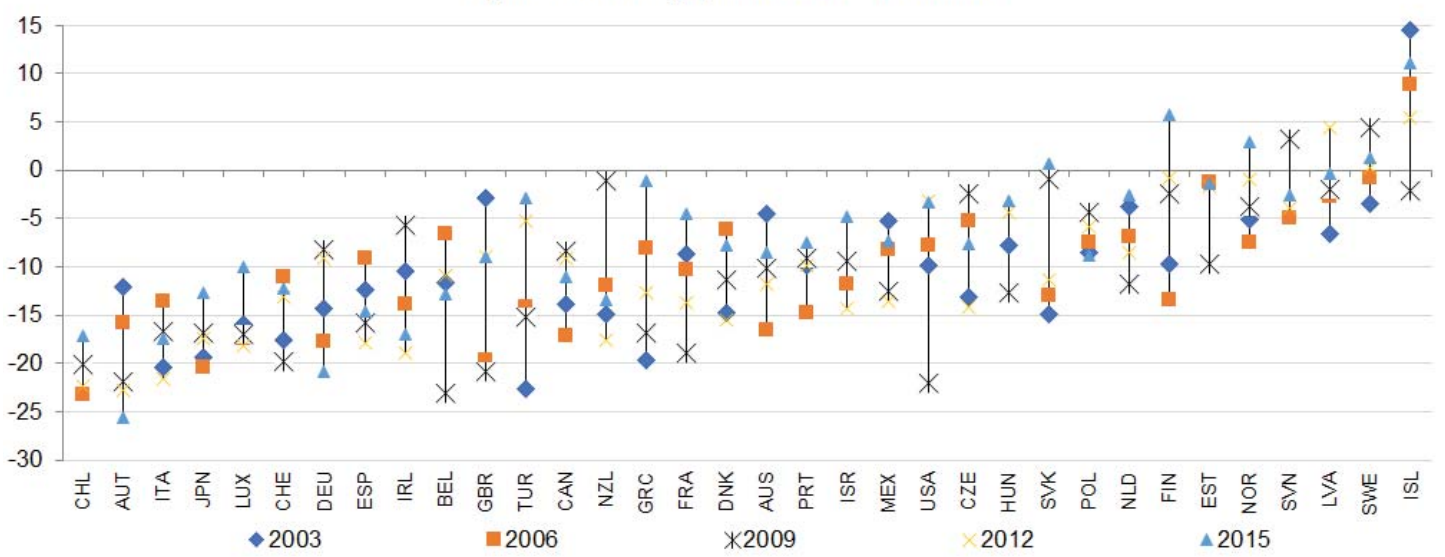

Note: Countries are ranked according to the average gender gap in Math over the period 2003-2015, from the more negative gender gap to more positive gender gap.

PISA sample of students above the median of the ESCS of each country.

Figure 2. Gender gap in Math. Non-OECD countries

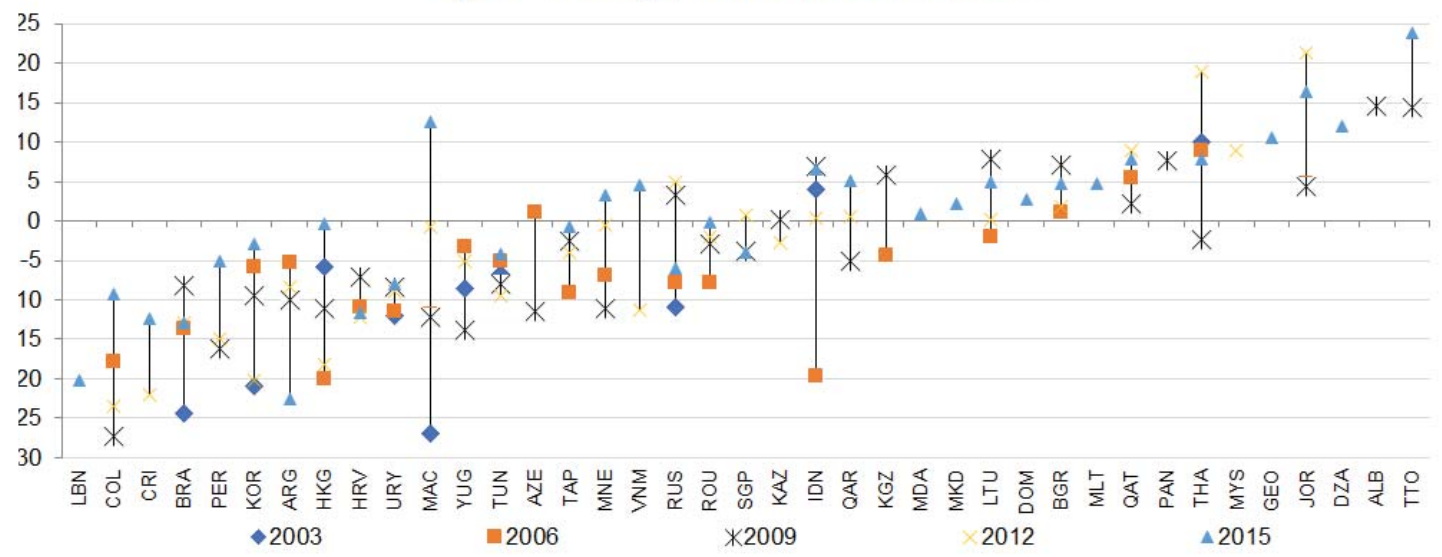

Note: Countries are ranked according to the average gender gap in Math over the period 2003-2015, from the more negative gender gap to more positive gender gap.

PISA sample of students above the median of the ESCS of each country.

\subsection{Country-level Gender Equality Measures}

Using country and year identifiers, we merge PISA data from these 73 countries with time-varying gender equality measures, obtaining a sample of 166 country/year data points for 34 OECD countries and 115 country/year data points for 38 non-OECD countries. In line with Guiso et al. (2008), we use several alternative and complementary measures of gender equality. In particular, we use the global Gender Gap Index (GGI hereafter), its four subindexes, and the female/male labor force participation ratio (FMLFP).

Both the GGI and the FMLFP ratio are available for virtually each country and year for which we have PISA data. ${ }^{6}$

The GGI is an index calculated by the World Economic Forum that measures the gap between men and women in four fundamental areas: economic participation and opportunity, political

\footnotetext{
${ }^{6}$ When using the FMLFP ratio, we lose one country (Macedonia) and when using the GGI, we lose another country (Macao-China). See Appendix Table A.1 for more details.
} 
empowerment, educational attainment, and health and survival (World Economic Forum, 2018). These dimensions are the four subindexes which form the global GGI. The global GGI aims at capturing the magnitude of gender-based disparities and tracking their progress over time. For all four subindexes, as well as for the global GGI (which is computed as a simple average of each subindex score), the highest possible score is 1 (gender parity) and the lowest possible score is 0 (imparity). The methodology used to compute the GGI, based on data compiled and/or collected by the World Economic Forum, has remained stable over time, providing a basis for robust comparisons across countries and over time.

The Economic Participation and Opportunity subindex captures three concepts: the labor force participation gap, the remuneration gap and the advancement gap (the latter being measured through the ratio of women to men among legislators, senior officials and managers, and the ratio of women to men among technical and professional workers).

The Political Empowerment subindex measures the gap between men and women at the highest level of political decision-making through the ratio of women to men in ministerial positions, the ratio of women to men in parliamentary positions, and the ratio of women to men in terms of years in executive office for the last 50 years.

The Educational Attainment subindex captures the gap between women's and men's current access to education through ratios of women to men in primary-, secondary- and tertiary-level education, and through the female to male ratio in literacy rates.

The Health and Survival subindex captures differences between women's and men's health through the sex ratio at birth and the gender gap in life expectancy. ${ }^{7}$

As stressed by the World Economic Forum (2018) the GGI measures gaps in outcomes "in access to resources and opportunities in countries, rather than the actual levels of the available resources and opportunities in those countries". Hence, the GGI ranks countries according to gender equality rather than women's empowerment in order to decouple it from countries' levels of development. Moreover, we use the ratio of female to male labor force participation ratio (FMLFP ratio, expressed as a percentage) as an additional and complementary measure of gender equality. The FMLFP ratio is constructed using data from the World Bank's World Development Indicators, and it measures the proportion of the individuals aged 15 and older who are available for producing goods and services in the market economy. ${ }^{8}$

Importantly, all the country-level indicators we consider reflect gender gaps in outcomes related to health, education, economic participation and political empowerment, rather than inputs (World Economic Forum, 2018). These outcomes are in turn the result of different inputs such as, for instance, culture, customs, or legislations. In other words, our gender equality indicators are likely the combined result of several policy, socioeconomic, and cultural variables. Hence, they should not be interpreted as reflecting neither culture alone nor the persistent component of cultural attitudes towards gender. ${ }^{9}$ As expected, our main gender equality indicators (the GGI and the

\footnotetext{
${ }^{7}$ For further details on the construction process of the global GGI and its four subindexes as well as the indicators they rely on see World Economic Forum (2018).

${ }^{8}$ Unpaid workers, family workers, and students are often omitted, and some countries do not count members of the armed forces

${ }^{9}$ Note that values and beliefs may also evolve in response to or in conjunction with changes in economic, social, or political conditions (see Inglehart and Welzel, 2005, Algan and Cahuc, 2010, Ananyev and Guriev, 2018, Giavazzi et al., 2019, and Zanella and Bellani, 2019, as well as the references therein).
} 
FMLFP ratio) are positively and significantly correlated with each other both in OECD $(0.7655$, $\mathrm{p}$-value $=0.00)$ and in non-OECD countries $(0.6727, \mathrm{p}$-value $=0.00)$.

On average, there is greater gender equality in OECD than non-OECD countries (see Table 1), as the averages of both the GGI and the FMLFP ratio are higher in OECD than in non-OECD countries ( 0.72 versus 0.68 for the GGI and $76.6 \%$ versus $69 \%$ for the FMLFP ratio). In line with this evidence, the correlations between these gender equality indicators and the GDP per capita in the full sample of countries are relatively large, positive and significant: 0.2508 ( $\mathrm{p}$-value $=0.00$ ) for the GGI, and 0.1871 (p-value $=0.0015$ ) for the FMLFP ratio.

One may expect cultural values involving gender or gender social norms to be quite stable over time, or, at least, to change more slowly than, for instance, economic, political, and educational indicators of gender equality. However, as discussed above, the GGI, its components, and the FMLFP likely reflect both cultural and non-cultural factors linked to gender equality. Hence, it is expected that their within country variability is not negligible. This indeed is shown in Table 2, where we have computed the percentage of the variation in all our gender equality indicators that can be attributed to within country-across time variation. To obtain these percentages we first compute the raw standard deviation of all our gender equality indicators in our pooled samples. Next, we regress those indicators on country fixed effects and obtain the residuals. Then we compute the standard deviation of those residuals (which reflect our gender equality indicators clean of country fixed effects or within country variation). Finally, we divide it by the raw standard deviation calculated initially.

Table 2. Percentage of the total variation in the math and reading gender gaps, and in different gender equality indicators attributable to within country-across time variation.

\begin{tabular}{|c|c|c|c|c|c|c|}
\hline & \multicolumn{2}{|c|}{ OECD countries } & \multicolumn{2}{|c|}{ Non-OECD countries } & \multicolumn{2}{|c|}{ All countries } \\
\hline & $\%$ & $\begin{array}{l}\text { No. of obs. } \\
\text { (countries } \\
\text { and years) }\end{array}$ & $\%$ & $\begin{array}{l}\text { No. of obs. } \\
\text { (countries } \\
\text { and years) }\end{array}$ & $\%$ & $\begin{array}{l}\text { No. of obs. } \\
\text { (countries } \\
\text { and years) }\end{array}$ \\
\hline Average Math gender gap & $61,46 \%$ & 166 & $54,86 \%$ & 125 & $54,71 \%$ & 291 \\
\hline Average Reading gender gap & $62,81 \%$ & 165 & $51,63 \%$ & 125 & $56,03 \%$ & 290 \\
\hline GGI & $37,85 \%$ & 166 & $33,28 \%$ & 115 & $33,58 \%$ & 281 \\
\hline Econ. index & $43,87 \%$ & 166 & $30,40 \%$ & 115 & $37,73 \%$ & 281 \\
\hline PEI & $35,48 \%$ & 166 & $36,61 \%$ & 115 & $32,07 \%$ & 281 \\
\hline Educ. index & $49,83 \%$ & 166 & $44,67 \%$ & 115 & $46,51 \%$ & 281 \\
\hline Health index & $24,92 \%$ & 166 & $47,70 \%$ & 115 & $23,41 \%$ & 281 \\
\hline FMLFP ratio & $24,10 \%$ & 166 & $9,04 \%$ & 119 & $15,90 \%$ & 285 \\
\hline
\end{tabular}

Such temporal variation can be exploited - on top of the cross-country variation illustrated in Appendix Table A.1 and Figures 1 and 2 that has been used by Guiso et al. (2008) - in order to estimate the effect of gender equality on the math gender gap while holding constant time-invariant unobserved factors.

\section{RESULTS}

\subsection{Replicating Guiso et al. (2008) Using 5 Waves of PISA Data}

As a benchmark for later comparisons, we begin replicating earlier findings from Guiso et al. (2008) by applying their statistical model to pooled data from five PISA waves spanning the 20032015 period. We regress the math gender gap for country $i$ at time $t\left(\mathrm{Y}_{\mathrm{it}}\right)$ on the country's gender 
Table 3. Gender gap in PISA Math test and gender equality measures. PISA sample of students above the median of ESCS of each country

Pooled cross-sectional analysis

\begin{tabular}{|c|c|c|c|c|c|c|}
\hline Panel A. Guiso et al. (2008) sample & $(1)$ & $(2)$ & (3) & (4) & (5) & (6) \\
\hline GGI & $\begin{array}{c}76.785^{* * *} \\
(15.412)\end{array}$ & & & & & \\
\hline Econ. index & & $\begin{array}{c}41.328 * * * \\
(8.751)\end{array}$ & & & & \\
\hline PEI & & & $\begin{array}{c}20.928 * * * \\
(6.447)\end{array}$ & & & \\
\hline Educ. index & & & & $\begin{array}{c}75.489 * * * \\
(16.539)\end{array}$ & & \\
\hline Health index & & & & & $\begin{array}{l}-42.328 \\
(69.946)\end{array}$ & \\
\hline FMLFP ratio & & & & & & $\begin{array}{c}0.260 * * * \\
(0.093)\end{array}$ \\
\hline Log of GDP pc in PPP & $\begin{array}{c}-7.930 * * * \\
(1.750)\end{array}$ & $\begin{array}{c}-6.863^{* * *} \\
(1.591)\end{array}$ & $\begin{array}{c}-6.371^{* * *} \\
(1.576)\end{array}$ & $\begin{array}{c}-4.619 * * \\
(1.884)\end{array}$ & $\begin{array}{c}-3.599 * * \\
(1.755)\end{array}$ & $\begin{array}{c}-5.720 * * * \\
(2.072)\end{array}$ \\
\hline Constant & $\begin{array}{c}17.656 \\
(15.196)\end{array}$ & $\begin{array}{c}33.937^{* *} \\
(14.691)\end{array}$ & $\begin{array}{c}51.726 * * * \\
(16.308)\end{array}$ & $\begin{array}{c}-36.318^{* *} \\
(17.668)\end{array}$ & $\begin{array}{c}69.137 \\
(65.817)\end{array}$ & $\begin{array}{c}30.377 \\
(18.337)\end{array}$ \\
\hline R-squared & $\begin{array}{c}0.266 \\
184\end{array}$ & $\begin{array}{c}0.244 \\
184\end{array}$ & $\begin{array}{c}0.184 \\
184\end{array}$ & $\begin{array}{c}0.086 \\
184\end{array}$ & $\begin{array}{c}0.060 \\
184\end{array}$ & $\begin{array}{c}0.133 \\
199\end{array}$ \\
\hline No. of countries & 37 & 37 & 37 & 37 & 37 & 40 \\
\hline Panel B. OECD countries & & & & & & \\
\hline GGI & $\begin{array}{c}78.920 * * * \\
(15.189)\end{array}$ & & & & & \\
\hline Econ. index & & $\begin{array}{c}43.429 * * * \\
(8.815)\end{array}$ & & & & \\
\hline PEI & & & $\begin{array}{c}22.205^{* * *} \\
(6.178)\end{array}$ & & & \\
\hline Educ. index & & & & $\begin{array}{c}66.288^{* * *} \\
(19.370)\end{array}$ & & \\
\hline Health index & & & & & $\begin{array}{l}-340.454 \\
(351.679)\end{array}$ & \\
\hline FMLFP ratio & & & & & & $\begin{array}{c}0.343 * * * \\
(0.106)\end{array}$ \\
\hline Log of GDP pc in PPP & $\begin{array}{c}-7.056 * * * \\
(1.790)\end{array}$ & $\begin{array}{c}-6.281 * * * \\
(1.360)\end{array}$ & $\begin{array}{c}-4.840 * * \\
(1.966)\end{array}$ & $\begin{array}{l}-2.173 \\
(2.369)\end{array}$ & $\begin{array}{l}-1.982 \\
(2.529)\end{array}$ & $\begin{array}{c}-5.973 * * * \\
(1.594)\end{array}$ \\
\hline Constant & $\begin{array}{c}6.759 \\
(16.439)\end{array}$ & $\begin{array}{c}26.448^{*} \\
(14.021)\end{array}$ & $\begin{array}{l}35.107 * \\
(20.193)\end{array}$ & $\begin{array}{c}-52.950 * * \\
(23.826)\end{array}$ & $\begin{array}{c}343.058 \\
(352.359)\end{array}$ & $\begin{array}{c}26.161 \\
(15.955)\end{array}$ \\
\hline R-squared & 0.266 & 0.230 & 0.177 & 0.027 & 0.030 & 0.184 \\
\hline Observations & 166 & 166 & 166 & 166 & 166 & 166 \\
\hline No. of countries & 34 & 34 & 34 & 34 & 34 & 34 \\
\hline Panel C. Non-OECD countries & & & & & & \\
\hline GGI & $\begin{array}{c}-10.435 \\
(51.838)\end{array}$ & & & & & \\
\hline Econ. index & & $\begin{array}{c}4.277 \\
(17.665)\end{array}$ & & & & \\
\hline PEI & & & $\begin{array}{c}-23.885 \\
(20.399)\end{array}$ & & & \\
\hline Educ. index & & & & $\begin{array}{c}54.539 \\
(52.962)\end{array}$ & & \\
\hline Health index & & & & & $\begin{array}{c}14.719 \\
(80.448)\end{array}$ & \\
\hline FMLFP ratio & & & & & & $\begin{array}{l}-0.095 \\
(0.095)\end{array}$ \\
\hline Log of GDP pc in PPP & $\begin{array}{c}0.866 \\
(1.832)\end{array}$ & $\begin{array}{c}0.978 \\
(1.891)\end{array}$ & $\begin{array}{c}0.655 \\
(1.667)\end{array}$ & $\begin{array}{c}0.952 \\
(1.728)\end{array}$ & $\begin{array}{c}0.996 \\
(1.710)\end{array}$ & $\begin{array}{c}0.720 \\
(1.379)\end{array}$ \\
\hline Constant & $\begin{array}{c}-4.842 \\
(44.584)\end{array}$ & $\begin{array}{l}-15.704 \\
(24.521)\end{array}$ & $\begin{array}{c}-6.868 \\
(17.585)\end{array}$ & $\begin{array}{c}-66.371 \\
(51.476)\end{array}$ & $\begin{array}{l}-27.440 \\
(76.713)\end{array}$ & $\begin{array}{c}-4.205 \\
(15.862)\end{array}$ \\
\hline R-squared & 0.006 & 0.006 & 0.031 & 0.015 & 0.005 & 0.023 \\
\hline Observations & 115 & 115 & 115 & 115 & 115 & 119 \\
\hline No. of countries & 38 & 38 & 38 & 38 & 38 & 38 \\
\hline
\end{tabular}

Notes: Standard errors clustered at country level in parentheses

$* * * \mathrm{p}<0.01, * * \mathrm{p}<0.05, * \mathrm{p}<0.1$ 
equality indicator $G E_{i t}$ (we will use the global GGI, its four subindexes and FMLFP) and the logarithm of its Gross Domestic Product (log $\left.G D P_{i t}\right)$ per capita in PPP as shown in equation (1) below:

$$
Y_{i t}=\alpha_{1}+\alpha_{2} G E_{i t}+\alpha_{3} \log G D P_{i t}+\varepsilon_{i t}
$$

Note that the estimated association between the math gender gap and the gender equality indicator in equation (1) is based on the cross-country variation in this indicator-while holding constant the level of economic development, proxied by the log of the GDP per capita.

In Panel A in Table 3, we use the same countries as in Guiso et al. (2008), but expand the analysis to the additional four waves of PISA data currently available. ${ }^{10}$ Each column uses an alternative measure of gender equality: the overall GGI, its four subindexes, and the FMLFP ratio. Panels B and $\mathrm{C}$ expand the analysis to additional countries available in PISA in waves two to five, with Panel B showing results for OECD countries, and Panel $\mathrm{C}$ showing results for non-OECD countries.

Consistent with Guiso et al. (2008), we generally observe a positive and statistically significant association between the female-male gender gap in math test scores and our different measures of gender equality in Panel A. Results from columns 1 and 2 indicate that Guiso et al. (2008) findings for 2003 still hold when including four additional waves of data. Note that their estimated effect of GGI falls within our $95 \%$ confidence interval.

Results from Panel B indicate that, in OECD countries with greater gender equality, girls perform better in math relative to boys than in OECD countries with lower gender equality. As most (75\%) of Guiso et al.'s sample consisted of OECD countries, this result corroborates their findings.

In contrast, Panel $\mathrm{C}$ in Table 3 reveals that the association between either measure of gender equality and the math gender gap in non-OECD countries is sometimes negative (albeit much smaller in absolute value than in OECD countries) and always far from statistically significant at standard levels of testing. This suggests that earlier findings appear to be sensitive to the level of economic development achieved in the countries under study. ${ }^{11}$ The results we obtain are very similar when we use the full sample of students (see Table A.2 in the Appendix ${ }^{12}$ ) rather than the sample of students in the upper half of each country socioeconomic status distribution as in Guiso et al. (2008) and our benchmark analyses.

\subsection{Controlling for PISA Cohort/Time Differences}

In Table 4, we modify Guiso et al. (2008) model to add year fixed effects $\left(\delta_{t}\right)$ with the purpose of accounting for PISA cohort differences and/or time variation. We estimate the new model - see equation (2) below - using the same country groups and measures of female emancipation as in Table 3 .

$$
Y_{i t}=\alpha_{1}+\alpha_{2} G E_{i t}+\alpha_{3} \log G D P_{i t}+\delta_{t}+\varepsilon_{i t}
$$

\footnotetext{
${ }^{10}$ Needless to say, when we estimate model (1) using data for year 2003 only, as Guiso et al. (2008) do, we are also able to replicate their findings.

${ }^{11}$ These findings are in line with the raw estimated correlations between our main gender equality indicators (the GGI and the FMLFP ratio) and the female-male math gender gap, which is positive and statistically significant in OECD countries, while this is not the case in non-OECD countries (see Appendix Figures A1-A4).

12 Please note that when we use the sample of all students, the total number of observations increases by two. In this sample there is one country (Albania) which has two more observations - for the years 2012 and 2015 - with respect to the case when we use only the sample of students who are above the median of the ESCS. For this country, the ESCS is not available for these two years (2012 and 2015), therefore we cannot include them in the estimations.
} 
Table 4. Gender gap in PISA Math test and gender equality measures. PISA sample of students above the median of ESCS of each country

Pooled cross-sectional analysis with year fixed effects

\begin{tabular}{|c|c|c|c|c|c|c|}
\hline Panel A. Guiso et al. (2008) sample & (1) & $(2)$ & (3) & (4) & (5) & (6) \\
\hline \multirow[t]{2}{*}{$\mathrm{GGI}$} & $73.717 * * *$ & & & & & \\
\hline & $(17.079)$ & & & & & \\
\hline \multirow[t]{2}{*}{ Econ. index } & & $39.442 * * *$ & & & & \\
\hline & & $(9.521)$ & & & & \\
\hline \multirow[t]{2}{*}{ PEI } & & & $19.875^{* * *}$ & & & \\
\hline & & & $(6.810)$ & & & \\
\hline \multirow[t]{2}{*}{ Educ. index } & & & & $64.309 * * *$ & & \\
\hline & & & & $(18.272)$ & & \\
\hline \multirow[t]{2}{*}{ Health index } & & & & & -39.680 & \\
\hline & & & & & $(70.692)$ & \\
\hline \multirow[t]{2}{*}{ FMLFP ratio } & & & & & & $0.251 * * *$ \\
\hline & & & & & & $(0.091)$ \\
\hline \multirow[t]{2}{*}{ Log of GDP pc in PPP } & $-7.942 * * *$ & $-6.874 * * *$ & $-6.507 * * *$ & $-4.766 * *$ & $-3.939 * *$ & $-5.999 * * *$ \\
\hline & $(1.759)$ & $(1.604)$ & $(1.585)$ & $(1.884)$ & $(1.771)$ & $(2.058)$ \\
\hline \multirow[t]{2}{*}{ Constant } & 19.299 & $34.764 * *$ & $52.265^{* * *}$ & -24.909 & 68.696 & $32.382^{*}$ \\
\hline & $(15.526)$ & $(14.852)$ & $(16.470)$ & $(19.921)$ & $(66.044)$ & $(18.341)$ \\
\hline \multirow[t]{2}{*}{ R-squared } & 0.280 & 0.256 & 0.210 & 0.119 & 0.101 & 0.180 \\
\hline & 184 & 184 & 184 & 184 & 184 & 199 \\
\hline No. of countries & 37 & 37 & 37 & 37 & 37 & 40 \\
\hline \multicolumn{7}{|l|}{ Panel B. OECD countries } \\
\hline \multirow[t]{2}{*}{ GGI } & $78.982 * * *$ & & & & & \\
\hline & $(17.678)$ & & & & & \\
\hline \multirow[t]{2}{*}{ Econ. index } & & $44.378 * * *$ & & & & \\
\hline & & $(10.715)$ & & & & \\
\hline \multirow[t]{2}{*}{ PEI } & & & $21.432 * * *$ & & & \\
\hline & & & $(6.666)$ & & & \\
\hline \multirow[t]{2}{*}{ Educ. index } & & & & $58.565^{* * *}$ & & \\
\hline & & & & $(19.472)$ & & \\
\hline \multirow[t]{2}{*}{ Health index } & & & & & -334.203 & \\
\hline & & & & & (354.687) & \\
\hline \multirow[t]{2}{*}{ FMLFP ratio } & & & & & & $0.338^{* * *}$ \\
\hline & & & & & & $(0.111)$ \\
\hline Log of GDP pc in PPP & $-7.163^{* * *}$ & $-6.457 * * *$ & $-4.927 * *$ & -2.326 & -2.273 & $-6.129 * * *$ \\
\hline & $(1.882)$ & $(1.419)$ & $(2.025)$ & $(2.412)$ & $(2.529)$ & $(1.633)$ \\
\hline Constant & 7.904 & $28.053^{*}$ & $35.682 *$ & $-44.304^{*}$ & 339.181 & $27.992 *$ \\
\hline & $(16.597)$ & $(14.027)$ & $(20.592)$ & $(24.151)$ & (355.112) & $(16.175)$ \\
\hline R-squared & 0.281 & 0.248 & 0.196 & 0.057 & 0.065 & 0.123 \\
\hline Observations & 166 & 166 & 166 & 166 & 166 & 166 \\
\hline No. of countries & 34 & 34 & 34 & 34 & 34 & 34 \\
\hline Panel C. Non-OECD countries & & & & & & \\
\hline GGI & -29.581 & & & & & \\
\hline & $(53.173)$ & & & & & \\
\hline Econ. index & & 1.943 & & & & \\
\hline & & $(17.549)$ & & & & \\
\hline PEI & & & $-37.433^{*}$ & & & \\
\hline & & & $(20.006)$ & & & \\
\hline Educ. index & & & & 37.450 & & \\
\hline & & & & (50.955) & & \\
\hline Health index & & & & & 7.029 & \\
\hline & & & & & (77.900) & \\
\hline FMLFP ratio & & & & & & -0.087 \\
\hline & & & & & & $(0.094)$ \\
\hline Log of GDP pc in PPP & 0.191 & 0.477 & -0.174 & 0.498 & 0.482 & 0.250 \\
\hline & $(1.895)$ & $(2.000)$ & $(1.694)$ & $(1.858)$ & $(1.835)$ & $(1.445)$ \\
\hline Constant & 9.309 & -14.061 & -3.514 & -49.455 & -19.746 & -6.673 \\
\hline & $(45.557)$ & $(24.851)$ & $(17.986)$ & $(52.355)$ & $(73.338)$ & $(16.439)$ \\
\hline R-squared & 0.074 & 0.065 & 0.124 & 0.069 & 0.065 & 0.104 \\
\hline Observations & 115 & 115 & 115 & 115 & 115 & 119 \\
\hline No. of countries & 38 & 38 & 38 & 38 & 38 & 38 \\
\hline
\end{tabular}

Notes: Standard errors clustered at country level in parentheses

*** $\mathrm{p}<0.01, * * \mathrm{p}<0.05, * \mathrm{p}<0.1$ 
This change delivers the same qualitative results as in Table 3: the relative under-performance of girls in math test scores generally significantly decreases with gender equality across OECD countries. However, no positive relationship is apparent between gender equality and the femalemale gender gap across non-OECD countries after controlling for time/cohort effects. This result also holds when using the full sample of students regardless of their socioeconomic status as shown in Appendix Table A.3.

\subsection{Controlling for Time-Invariant Unobserved Heterogeneity at the Country Level}

Even though all the models estimated so far control for the countries' level of economic development by including the log of the GDP per capita as an explanatory variable, it is plausible that previous results are due to the presence of country-level unobserved factors potentially affecting both the math gender gap and our gender equality indicators. To address this concern, in Table 5 we estimate model (3), which adds country fixed effects $\left(\delta_{i}\right)$ to model (2):

$$
Y_{i t}=\alpha_{1}+\alpha_{2} G E_{i t}+\alpha_{3} \log G D P_{i t}+\delta_{t}+\delta_{i}+\varepsilon_{i t}
$$

Doing so implies that we are now eliminating the influence of time-invariant country-specific characteristics by exploiting changes in gender equality within each country over time to identify the effect of gender equality indicators on the math gender gap. The analysis is again shown for the Guiso et al. (2008) sample (Panel A), OECD countries (Panel B), and non-OECD countries (Panel C) for the period 2003-2015.

The comparison of the first columns of Panel A in Tables 3, 4, and 5 reveals that including country and year fixed effects changes the sign of the estimated coefficient of the GGI, which is now negative, considerably smaller in absolute value, and no longer statistically significant. Note also that Guiso et al.'s (2008) estimated effect of the GGI does not fall within our 95\% confidence interval. This indicates that, once we account for country-specific time-invariant idiosyncrasies, the positive and statistically significant association between the GGI and the math gender gap in the sample of countries used in Guiso et al. (2008) vanishes. The same conclusion is generally reached if we focus on OECD countries (Panel B) - which is to be expected as Guiso et al. (2008) sample consisted mostly of OECD countries ${ }^{13}$-, and if we use alternative indicators of gender equality (Columns 2-6).

In sum, findings from Table 5 reveal that results from cross-sectional analyses no longer hold once country-specific unobserved determinants of the math gender gap are accounted for, both in the sample of countries used in Guiso et al. (2008) — most of which belong to the OECD — and in the sample of OECD countries currently available in PISA over the 2003-2015 period.

As for non-OECD countries, results from Panel C in Table 5 yield the same conclusion obtained when previously estimating equations (1) and (2) in Panel C of Tables 3 and 4, respectively: there is no positive and significant association between gender equality and the female-male math gender gap. Appendix Table A.4 shows similar results for the full sample of PISA students.

In the next section we further investigate the different pattern of results between OECD and nonOECD countries.

${ }^{13} 29$ countries in the sample of Guiso et al. (2008) are OECD country, which is about $75 \%$ of their total sample. 
Table 5. Gender gap in PISA Math test and gender equality measures. PISA sample of students above the median of ESCS of each country

Panel analysis (with year and country fixed effects)

\begin{tabular}{|c|c|c|c|c|c|c|}
\hline Panel A. Guiso et al. (2008) sample & (1) & (2) & (3) & (4) & (5) & (6) \\
\hline \multirow[t]{2}{*}{ GGI } & -5.103 & & & & & \\
\hline & $(29.114)$ & & & & & \\
\hline \multirow[t]{2}{*}{ Econ. index } & & -15.249 & & & & \\
\hline & & $(16.541)$ & & & & \\
\hline \multirow[t]{2}{*}{ PEI } & & & 1.355 & & & \\
\hline & & & $(10.190)$ & & & \\
\hline \multirow[t]{2}{*}{ Educ. index } & & & & $76.009 *$ & & \\
\hline & & & & $(42.621)$ & & \\
\hline \multirow[t]{2}{*}{ Health index } & & & & & -111.527 & \\
\hline & & & & & $(177.352)$ & \\
\hline \multirow[t]{2}{*}{ FMLFP ratio } & & & & & & -0.185 \\
\hline & & & & & & $(0.280)$ \\
\hline \multirow[t]{2}{*}{ Log of GDP pc in PPP } & 10.176 & 8.118 & 10.377 & 6.990 & 10.767 & $16.270^{*}$ \\
\hline & (7.116) & (7.336) & $(6.896)$ & $(6.801)$ & $(6.874)$ & $(8.839)$ \\
\hline \multirow[t]{2}{*}{ Constant } & -109.859 & -82.816 & -115.725 & $-155.883^{* *}$ & -10.703 & -162.898 \\
\hline & $(82.041)$ & (80.190) & (70.395) & $(62.956)$ & $(194.732)$ & $(104.362)$ \\
\hline \multirow[t]{2}{*}{ R-squared } & 0.099 & 0.104 & 0.099 & 0.113 & 0.101 & 0.168 \\
\hline & 184 & 184 & 184 & 184 & 184 & 199 \\
\hline No. of countries & 37 & 37 & 37 & 37 & 37 & 40 \\
\hline \multicolumn{7}{|l|}{ Panel B. OECD countries } \\
\hline \multirow[t]{2}{*}{ GGI } & -15.873 & & & & & \\
\hline & $(26.018)$ & & & & & \\
\hline \multirow[t]{2}{*}{ Econ. index } & & -14.123 & & & & \\
\hline & & $(17.083)$ & & & & \\
\hline \multirow[t]{2}{*}{ PEI } & & & -3.204 & & & \\
\hline & & & $(8.490)$ & & & \\
\hline \multirow[t]{2}{*}{ Educ. index } & & & & 59.455 & & \\
\hline & & & & $(42.600)$ & & \\
\hline \multirow[t]{2}{*}{ Health index } & & & & & -52.777 & \\
\hline & & & & & $(278.434)$ & \\
\hline \multirow[t]{2}{*}{ FMLFP ratio } & & & & & & $-0.404 *$ \\
\hline & & & & & & $(0.206)$ \\
\hline Log of GDP pc in PPP & 8.401 & 7.000 & 8.701 & 5.867 & 9.077 & 5.460 \\
\hline & (9.318) & (9.439) & $(9.238)$ & $(8.631)$ & (9.194) & $(10.126)$ \\
\hline Constant & -86.311 & -74.011 & -99.902 & -129.983 & -52.965 & -37.259 \\
\hline & (103.455) & $(102.403)$ & (95.855) & (88.054) & (289.703) & (111.930) \\
\hline R-squared & 0.104 & 0.107 & 0.103 & 0.113 & 0.102 & 0.123 \\
\hline Observations & 166 & 166 & 166 & 166 & 166 & 166 \\
\hline No. of countries & 34 & 34 & 34 & 34 & 34 & 34 \\
\hline Panel C. Non-OECD countries & & & & & & \\
\hline GGI & 18.970 & & & & & \\
\hline & $(60.565)$ & & & & & \\
\hline Econ. index & & 2.212 & & & & \\
\hline & & $(15.587)$ & & & & \\
\hline PEI & & & 6.821 & & & \\
\hline & & & (30.143) & & & \\
\hline Educ. index & & & & 7.680 & & \\
\hline & & & & $(67.597)$ & & \\
\hline Health index & & & & & -35.444 & \\
\hline & & & & & $(128.428)$ & \\
\hline FMLFP ratio & & & & & & 0.348 \\
\hline & & & & & & $(0.420)$ \\
\hline Log of GDP pc in PPP & 0.379 & 0.783 & 0.407 & 0.603 & 0.597 & 12.085 \\
\hline & $(9.356)$ & $(9.074)$ & $(9.413)$ & $(9.444)$ & (9.297) & $(10.252)$ \\
\hline Constant & -22.452 & -15.026 & -10.787 & -19.457 & 22.411 & -146.554 \\
\hline & $(86.998)$ & (85.658) & (87.859) & $(89.490)$ & (192.658) & (110.605) \\
\hline R-squared & 0.140 & 0.140 & 0.140 & 0.140 & 0.140 & 0.213 \\
\hline Observations & 115 & 115 & 115 & 115 & 115 & 119 \\
\hline No. of countries & 38 & 38 & 38 & 38 & 38 & 38 \\
\hline
\end{tabular}

Notes:

Standard errors clustered at country level in parentheses

*** $\mathrm{p}<0.01,{ }^{* *} \mathrm{p}<0.05,{ }^{*} \mathrm{p}<0.1$ 


\subsection{Non-linearities}

Non-OECD countries are on average poorer than OECD countries, but using GDP per capita to group countries according to their level of development is likely more accurate and may allow us to dig deeper into the different pattern of results between OECD and non-OECD countries. In particular, we have estimated our preferred model (with country and year fixed effects) including different gender equality measures on the right-hand side as well as GDP per capita quartiles and their interactions with the gender equality indicators. That is, we estimate the following equation:

$$
Y_{i t}=\alpha_{1}+\alpha_{2} G E_{i t}+\sum_{j=1}^{3} \gamma_{\mathrm{j}} G E_{i t} * Q_{j i t}+\sum_{j=1}^{3} \delta_{\mathrm{j}} Q_{j i t}+\delta_{t}+\delta_{i}+\varepsilon_{i t}
$$

where $Y_{i t}$ is the math gender gap of country $i$ at time $t, G E_{i t}$ is one of our gender equality indicators (the global GGI, the four subindexes of the GGI and the FMLFP ratio) and $Q_{j i t}$ is a dummy variable which takes the value 1 if the GDP per capita in PPP of country $i$ at time $t$ is in the $j t h$ quartile (the reference category is the $4^{\text {th }}$ quartile, where GDP per capita in PPP is above the $75^{\text {th }}$ percentile). $\delta_{t}$ are year fixed effects and $\delta_{i}$ are country fixed effects.

These regression results are displayed in Tables 6 and 7 for the sample of students whose socioeconomic status is above the median and for the full sample of students, respectively. We find that, when using two of our gender equality indicators (the overall GGI and its Political Empowerment subindex when using the sample of students above the median of ESCS, and the overall GGI and its Health subindex when using the full sample), their effect on the female-male math gender gap is significantly larger in countries at the bottom quartile of the GDP distribution than in their fourth quartile counterparts.

Additionally, in Table 8 we report the effect of our gender equality indicators on the female-male math gender gap for countries in the bottom quartile of the GDP distribution (that is, we display $\widehat{\alpha_{2}}+\widehat{\gamma_{1}}$ and their associated standard errors). We find that the estimated effects are significant and positive in the poorest countries of our sample when using the GGI, as well as its Political Empowerment and Education subindexes (and when using its Health subindex if we do not restrict the sample to students whose ESCS index is above the median).

In sum, we find that, on average, gender equality is not significantly associated with the femalemale gender gap once time-invariant unobserved heterogeneity is accounted for (as discussed in Section 3.3). However, non-linear effects are relevant, as we also find that gender equality is significantly and positively associated with the female-male math gender gap in countries at the bottom of the GDP per capita distribution. 
Table 6. Gender gap in PISA Math test and gender equality measures. Panel analysis (with year and country fixed effects). PISA sample of students above the median of the ESCS of each country.

\begin{tabular}{|c|c|c|c|c|c|c|}
\hline & $(1)$ & $(2)$ & (3) & (4) & (5) & (6) \\
\hline \multirow[t]{2}{*}{ GGI } & -16.816 & & & & & \\
\hline & $(29.381)$ & & & & & \\
\hline \multirow[t]{2}{*}{$\mathrm{GG} \mid * \mathrm{Q} 1$} & $101.519 * *$ & & & & & \\
\hline & $(48.858)$ & & & & & \\
\hline \multirow[t]{2}{*}{$\mathrm{GG} / * \mathrm{Q} 2$} & 9.834 & & & & & \\
\hline & $(38.873)$ & & & & & \\
\hline \multirow[t]{2}{*}{$\mathrm{GG} / * \mathrm{Q} 3$} & -16.903 & & & & & \\
\hline & (26.281) & & & & & \\
\hline \multirow[t]{2}{*}{ EOI } & & -9.771 & & & & \\
\hline & & (12.940) & & & & \\
\hline \multirow[t]{2}{*}{$\mathrm{EOI}{ }^{*} \mathrm{Q} 1$} & & 7.477 & & & & \\
\hline & & $(25.411)$ & & & & \\
\hline \multirow[t]{2}{*}{$\mathrm{EOI} * \mathrm{Q} 2$} & & -12.875 & & & & \\
\hline & & $(19.801)$ & & & & \\
\hline \multirow[t]{2}{*}{$\mathrm{EOI} * \mathrm{Q} 3$} & & -10.756 & & & & \\
\hline & & $(16.436)$ & & & & \\
\hline \multirow[t]{2}{*}{ PEI } & & & -3.288 & & & \\
\hline & & & $(12.542)$ & & & \\
\hline \multirow[t]{2}{*}{ PEI*Q1 } & & & $48.859 * *$ & & & \\
\hline & & & (23.595) & & & \\
\hline \multirow[t]{2}{*}{$\mathrm{PEI} * \mathrm{Q} 2$} & & & 3.394 & & & \\
\hline & & & (13.567) & & & \\
\hline \multirow[t]{2}{*}{$\mathrm{PEI} * \mathrm{Q} 3$} & & & -6.844 & & & \\
\hline & & & $(9.268)$ & & & \\
\hline \multirow[t]{2}{*}{ Educ.index } & & & & -21.363 & & \\
\hline & & & & (92.934) & & \\
\hline \multirow[t]{2}{*}{ Educ.index*Q1 } & & & & 151.032 & & \\
\hline & & & & (101.322) & & \\
\hline \multirow[t]{2}{*}{ Educ.index*Q2 } & & & & 69.929 & & \\
\hline & & & & (99.957) & & \\
\hline \multirow[t]{2}{*}{ Educ.index*Q3 } & & & & -8.887 & & \\
\hline & & & & (104.090) & & \\
\hline Health index & & & & & -166.172 & \\
\hline & & & & & (115.652) & \\
\hline Health index*Q1 & & & & & 317.150 & \\
\hline & & & & & (195.708) & \\
\hline Health index*Q2 & & & & & 121.607 & \\
\hline & & & & & (193.848) & \\
\hline Health index*Q3 & & & & & -54.708 & \\
\hline & & & & & $(105.854)$ & \\
\hline FMLFP ratio & & & & & & -0.190 \\
\hline & & & & & & (0.419) \\
\hline FMLFP ratio*Q1 & & & & & & 0.107 \\
\hline & & & & & & $(0.477)$ \\
\hline FMLFP ratio*Q2 & & & & & & -0.060 \\
\hline & & & & & & $(0.445)$ \\
\hline FMLFP ratio*Q3 & & & & & & -0.457 \\
\hline & & & & & & $(0.354)$ \\
\hline Q1 & $-68.669 * *$ & -5.480 & -6.378 & -150.018 & -312.381 & -2.746 \\
\hline & (33.588) & (16.799) & $(4.428)$ & $(100.854)$ & (191.510) & (37.568) \\
\hline Q2 & -4.922 & 9.564 & 1.125 & -68.873 & -118.695 & 10.163 \\
\hline & $(27.256)$ & (13.534) & (3.171) & (99.572) & (188.937) & (35.279) \\
\hline Q3 & 14.530 & 9.569 & 4.000 & 10.478 & 54.794 & 39.389 \\
\hline & (19.660) & (12.168) & $(2.900)$ & (103.549) & (102.706) & (29.439) \\
\hline Constant & 2.506 & -2.965 & $-8.498 * * *$ & 13.337 & 154.412 & 0.692 \\
\hline & $(20.834)$ & (9.301) & $(3.001)$ & (92.314) & (113.269) & (33.580) \\
\hline R-squared & 0.141 & 0.125 & 0.139 & 0.144 & 0.122 & 0.152 \\
\hline Observations & 281 & 281 & 281 & 281 & 281 & 285 \\
\hline No. of countries & 72 & 72 & 72 & 72 & 72 & 72 \\
\hline
\end{tabular}

Notes: Standard errors clustered at country level in parentheses

*** $p<0.01,{ }^{* *} p<0.05, * p<0.1$

Q1, Q2 and Q3 are dummy variables corresponding the the 1st, 2nd and 3rd quartile of the distribution of the GDP pc in PPP of each country in the sample (Q4 is the reference category). Estimations using PISA2003-2015. 
Table 7. Gender gap in PISA Math test and gender equality measures. Panel analysis (with year and country fixed effects). PISA sample of all students

\begin{tabular}{|c|c|c|c|c|c|c|}
\hline & $(1)$ & (2) & (3) & (4) & $(5)$ & (6) \\
\hline GGI & $\begin{array}{c}-6.970 \\
(24.985)\end{array}$ & & & & & \\
\hline GGI*Q1 & $\begin{array}{c}96.193 * * \\
(42.528)\end{array}$ & & & & & \\
\hline $\mathrm{GG} \mid * \mathrm{Q} 2$ & $\begin{array}{c}22.400 \\
(39.673)\end{array}$ & & & & & \\
\hline $\mathrm{GG} \mid * \mathrm{Q} 3$ & $\begin{array}{l}-33.039 \\
(23.609)\end{array}$ & & & & & \\
\hline EOI & & $\begin{array}{c}-8.982 \\
(12.477)\end{array}$ & & & & \\
\hline EOI*Q1 & & $\begin{array}{l}11.240 \\
(23.514)\end{array}$ & & & & \\
\hline $\mathrm{EO} *{ }^{*} \mathrm{Q} 2$ & & $\begin{array}{l}-10.465 \\
(22.698)\end{array}$ & & & & \\
\hline EOI*Q3 & & $\begin{array}{l}-25.472 \\
(16.267)\end{array}$ & & & & \\
\hline PEI & & & $\begin{array}{c}1.078 \\
(10.485)\end{array}$ & & & \\
\hline $\mathrm{PEI} * \mathrm{Q} 1$ & & & $\begin{array}{c}30.298 \\
(19.082)\end{array}$ & & & \\
\hline $\mathrm{PEI} * \mathrm{Q} 2$ & & & $\begin{array}{c}8.262 \\
(12.991)\end{array}$ & & & \\
\hline PEI*Q3 & & & $\begin{array}{l}-10.204 \\
(7.843)\end{array}$ & & & \\
\hline Educ.index & & & & $\begin{array}{c}1.733 \\
(71.812)\end{array}$ & & \\
\hline Educ.index*Q1 & & & & $\begin{array}{c}89.993 \\
(76.241)\end{array}$ & & \\
\hline Educ.index*Q2 & & & & $\begin{array}{c}35.553 \\
(77.795)\end{array}$ & & \\
\hline Educ.index*Q3 & & & & $\begin{array}{r}-105.950 \\
(79.950)\end{array}$ & & \\
\hline Health index & & & & & $\begin{array}{l}-138.260 \\
(114.958)\end{array}$ & \\
\hline Health index*Q1 & & & & & $\begin{array}{c}487.117^{* * *} \\
(155.197)\end{array}$ & \\
\hline Health index*Q2 & & & & & $\begin{array}{c}268.668 \\
(333.039)\end{array}$ & \\
\hline Health index*Q3 & & & & & $\begin{array}{c}-140.687^{*} \\
(74.508)\end{array}$ & \\
\hline FMLFP ratio & & & & & & $\begin{array}{l}-0.151 \\
(0.372)\end{array}$ \\
\hline FMLFP ratio*Q1 & & & & & & $\begin{array}{c}0.181 \\
(0.403)\end{array}$ \\
\hline FMLFP ratio*Q2 & & & & & & $\begin{array}{l}-0.037 \\
(0.411)\end{array}$ \\
\hline FMLFP ratio*Q3 & & & & & & $\begin{array}{l}-0.535^{*} \\
(0.302)\end{array}$ \\
\hline Q1 & $\begin{array}{c}-64.893 * * \\
(29.002)\end{array}$ & $\begin{array}{c}-6.964 \\
(15.651)\end{array}$ & $\begin{array}{l}-4.794 \\
(4.002)\end{array}$ & $\begin{array}{l}-90.375 \\
(76.003)\end{array}$ & $\begin{array}{c}-479.422 * * * \\
(151.693)\end{array}$ & $\begin{array}{c}-8.569 \\
(31.472)\end{array}$ \\
\hline Q2 & $\begin{array}{l}-15.338 \\
(27.585)\end{array}$ & $\begin{array}{c}6.990 \\
(15.547)\end{array}$ & $\begin{array}{l}-2.198 \\
(3.590)\end{array}$ & $\begin{array}{l}-37.124 \\
(77.461)\end{array}$ & $\begin{array}{l}-265.585 \\
(325.282)\end{array}$ & $\begin{array}{c}6.205 \\
(32.114)\end{array}$ \\
\hline Q3 & $\begin{array}{c}24.967 \\
(17.642)\end{array}$ & $\begin{array}{c}18.634 \\
(11.815)\end{array}$ & $\begin{array}{c}3.319 \\
(2.755)\end{array}$ & $\begin{array}{l}105.245 \\
(79.487)\end{array}$ & $\begin{array}{c}136.562^{*} \\
(71.841)\end{array}$ & $\begin{array}{l}44.107^{*} \\
(25.124)\end{array}$ \\
\hline Constant & $\begin{array}{c}-2.992 \\
(17.551)\end{array}$ & $\begin{array}{l}-2.746 \\
(8.757)\end{array}$ & $\begin{array}{c}-7.376^{* * *} \\
(2.719)\end{array}$ & $\begin{array}{c}-7.909 \\
(71.510)\end{array}$ & $\begin{array}{c}129.868 \\
(112.261)\end{array}$ & $\begin{array}{c}-0.114 \\
(29.321)\end{array}$ \\
\hline R-squared & 0.149 & 0.133 & 0.135 & 0.144 & 0.143 & 0.159 \\
\hline Observations & 283 & 283 & 283 & 283 & 283 & 287 \\
\hline No. of countries & 72 & 72 & 72 & 72 & 72 & 72 \\
\hline
\end{tabular}

Notes: Standard errors clustered at country level in parentheses

*** $p<0.01,{ }^{* *} p<0.05,{ }^{*} p<0.1$

Q1, Q2 and Q3 are dummy variables corresponding the the 1st, 2nd and 3rd quartile of the distribution of the GDP pc in PPP of each country in the sample (Q4 is the reference category). Estimations using PISA2003-2015. 


\begin{tabular}{|c|c|c|}
\hline & $\begin{array}{c}\text { Table } 6 \text { (Sample of students } \\
\text { above the median of ESCS of } \\
\text { each country) }\end{array}$ & $\begin{array}{c}\text { Table } 7 \text { (Sample of all } \\
\text { students) }\end{array}$ \\
\hline & Summ of coeff. & Summ of coeff. \\
\hline \multirow[t]{2}{*}{$\mathrm{GGI}+\mathrm{Q} 1 * \mathrm{GGI}$} & $84.702^{*}$ & $89.223^{* *}$ \\
\hline & $(48,398)$ & $(41,944)$ \\
\hline \multirow[t]{2}{*}{$\mathrm{EOI}+\mathrm{Q} 1 * \mathrm{EOI}$} & -2.294 & 2.258 \\
\hline & $(23,403)$ & $(22,087)$ \\
\hline \multirow[t]{2}{*}{$\mathrm{PEI}+\mathrm{Q} 1$ * PEI } & $45.571^{* *}$ & $31.377^{*}$ \\
\hline & $(22,407)$ & $(17,771)$ \\
\hline \multirow[t]{2}{*}{ Educ.index + Q1 * Educ.index } & $129.669 * * *$ & $91.726^{* * *}$ \\
\hline & $(45,796)$ & $(31,318)$ \\
\hline \multirow[t]{2}{*}{ Health index + Q1 * Health index } & 150.978 & $348.858^{* * *}$ \\
\hline & $(171,290)$ & $(110,984)$ \\
\hline \multirow[t]{2}{*}{ FMLFP ratio + Q1 * FMLFP ratio } & -0.083 & 0.029 \\
\hline & $(0,258)$ & $(0,212)$ \\
\hline
\end{tabular}

Notes: Standard errors in parentheses.

*** $p<0.01, * * p<0.05, * p<0.1$

\section{ROBUSTNESS CHECKS}

\subsection{Controlling for Student-Level Heterogeneity}

One potential concern with the country-level analyses presented so far is that they may mask systematic differences in student characteristics across countries that could be driving the results. To control for student-level (and not just country-level) heterogeneity, we reran our regressions at the student level and used multilevel models. Level 1 observations (students) are treated as nested within Level 2 observations (countries), and we allow Level 1 effects to vary across countries and over time. In the first level, we estimate equation (4) separately for each country $i$ and year $t$ across $j$ students:

$$
\text { Math Test } \text { Score }_{j}=\beta_{1}+\beta_{2} \text { Female }_{j}+\beta_{3} X_{j}+\mu_{j}
$$

where the left-hand-side variable is student $j$ 's math test score, and the main covariate is a female dummy equal to 1 if the student is as female and 0 otherwise. In addition, we include a vector of covariates, $X_{j}$, that controls for whether student $j$ is at grade level, the student's age as well as his or her mother's and father's education level and employment status. In all student-level estimations, each observation is weighted using the students' final weights provided in PISA. Hence, $\hat{\beta}_{2 i t}$ is the average adjusted math gender gap in country $i$ and year $t$.

In Level 2 analysis, we regress the estimated coefficient on the female dummy from Level 1, $\hat{\beta}_{2 i t}$, on the country-and-year-level variables previously used:

$$
\hat{\beta}_{2 i t}=\alpha_{1}+\alpha_{2} G E_{i t}+\alpha_{3} \log G D P_{i t}+\delta_{t}+\delta_{i}+\varepsilon_{i t}
$$

Consistent with our previous evidence, this analysis confirms that, on average, gender equality is not significantly associated at standard levels of testing with the female-male gender gap once 
time-invariant unobserved heterogeneity as well as student-level observed heterogeneity are accounted for (see Appendix Table A.5).

Next, we estimate equation (7) in order to check whether our previous results on non-linearities still hold when controlling for student-level heterogeneity:

$$
\hat{\beta}_{2 i t}=\alpha_{1}+\alpha_{2} G E_{i t}+\sum_{j=1}^{3} \gamma_{\mathrm{j}} G E_{i t} * Q_{j i t}+\sum_{j=1}^{3} \delta_{\mathrm{j}} Q_{j i t}+\delta_{t}+\delta_{i}+\varepsilon_{i t}
$$

Also, in line with our previous results, we find that the effects of several gender equality indicators (the overall GGI as well as its political and educational subindexes) on the female-male math gender gap are significantly larger in countries at the bottom quartile of the GDP distribution than in their fourth quartile counterparts. ${ }^{14}$

As for the estimated effects of our gender equality indicators on the female-male math gender gap for countries in the bottom quartile of the GDP distribution (that is, $\widehat{\alpha_{2}}+\widehat{\gamma_{1}}$ ), we find that they are indeed significant and positive in the poorest countries of our sample when using the GGI, as well as its Political Empowerment, Education and Health subindexes (Appendix Table A.6) while controlling for student-level observed heterogeneity.

\subsection{Reading Test Scores}

Previous studies have investigated whether gender equality (Guiso et al. 2008) and gender social norms (Rodríguez-Planas and Nollenberger 2018) are associated with the gender gap in academic performance more broadly by looking into the gender gap in reading test scores.

Note that the gender gap tends to be reversed in reading with girls outperforming boys (see Column 4 in Appendix Table A.1). Table 1 shows that girls over-perform boys in reading by about 30 points on average both in OECD and in non-OECD countries, respectively.

Guiso et al. (2008) found that in countries with more gender equality the female-male reading gap is larger. In contrast with this finding, and in line with our previous results for math test scores, we

find that, on average, gender equality is not significantly and positively associated with the femalemale gap in reading test scores once unobserved permanent heterogeneity is accounted for. ${ }^{15}$

Next, we assess whether the non-linearities we uncovered for math test scores expand to reading by estimating model (4) using reading test scores as the dependent variable. In Appendix Table A.7, we report estimates of $\widehat{\alpha_{2}}+\widehat{\gamma_{1}}$, as well as their associated standard errors, that is, the estimated effects of our gender equality indicators on the reading gender gap for countries in the bottom quartile of the per capita GDP distribution.

In contrast with the non-linearities uncovered for math test scores, it appears that more gender equality is in general not associated with a significant widening of girls' comparative advantage in reading, neither on average, nor in countries in the bottom quartile of the GDP distribution (as shown in Appendix Table A.7).

\footnotetext{
14 These results are available upon request from the authors.

15 These results are available upon request from the authors.
} 


\section{CONCLUSION}

Our analysis uncovers two important findings regarding the association between gender equality and the math gender gap. First, we find that earlier cross-sectional findings are not robust to controlling for country-specific time-invariant confounding factors. Once we control for timeinvariant unobserved country heterogeneity, the positive and significant association between different indicators of gender equality and the relative performance of girls in mathematics (or reading) vanishes in both Guiso et al. (2008) original sample (which consisted mostly of OECD countries) and in the 34 OECD countries surveyed by PISA. This could be due to the fact that, as, other authors have suggested, the math gender gap in OECD countries might be more robustly linked to general measures of countries' societal inequalities not directly focused on gender. For instance, Breda et al. (2018) find that the math gender gap is associated with general indicators of societal inequalities (such as income Gini index or the variance in the socioeconomic background of a country's students) that are not directly related to gender. As regards non-OECD countries, we find no significant and positive association between gender equality and the female-male gender gap regardless of the empirical strategy used.

Second, we also find that the strength and significance of the association between gender equality and the math gender gap varies depending on countries' level of development. In particular, we uncover a positive and significant association between several gender equality indicators and the math gender gap in countries in the bottom quartile of the GDP per capita distribution. Gender equality is negatively associated with GDP per capita, so our finding implies that an improvement in gender equality indicators is associated with a narrowing of the math gender gap in poorer countries, but not in richer countries with higher levels of gender equality. It could be the case that, since the gender-neutral goal of subsistence is removed in richer countries, there is more scope for the manifestation of gender-specific ambitions and preferences (Falk and Hermle, 2018). Therefore, greater equality in access to opportunities may not necessarily imply a reduction in the gender gap in preferences towards math and math performance in richer countries. In contrast, the availability of material social resources is limited in poorer countries, where greater gender equality indeed translates into an improvement in girls' relative math performance because the unrestricted expression of preferences crucially depends on the fulfillment of material needs. 


\section{References}

Algan, Y. and Cahuc, P. (2010). Inherited trust and growth. American Economic Review, 100(5), 2060-92.

Antecol, H. 2000. An Examination of Cross-Country Differences in the Gender Gap in Labor Force Participation Rates. Labour Economics, 74: 409-26

Antecol, H. 2001. Why is there interethnic variation in the gender wage gap?: The role of cultural factors. Journal of Human Resources, 361: 119-143.

Ananyev, M. and Guriev, S. (2019). Effect of income on trust: evidence from the 2009 economic crisis in Russia. The Economic Journal, 129(619), 1082-1118.

Bedard, K., \& Cho, I. (2010). Early gender test score gaps across OECD countries. Economics of Education Review, 29(3), 348-363.

Breda, T., Jouini, E. and C. Napp. 2018. "Societal Inequalities Amplify Gender Gaps in Math." Science, 359: pp. 1219-20.

Ellison, G., \& Swanson, A. (2010). The gender gap in secondary school mathematics at high achievement levels: Evidence from the American Mathematics Competitions. Journal of Economic Perspectives, 24(2), 109-28.

Falk, A., \& Hermle, J. (2018). Relationship of gender differences in preferences to economic development and gender equality. Science, 362 (6412).

Fryer, R. and S. Levitt. 2010. "An Empirical Analysis of the Gender Gap in Mathematics." American Economic Journal: Applied Economics, 2(2): pp. 210-40.

Giavazzi, F., Petkov, I. and Schiantarelli, F. (2019). Culture: Persistence and evolution. Journal of Economic Growth, 24(2), 117-154.

Guiso, L., Monte F., Sapienza P. and L. Zingales. 2008. "Culture, Gender, and Math.” Science, 320: pp. 1164-65.

Inglehart, R. and Welzel, C. (2005). Modernization, cultural change, and democracy: The human development sequence. Cambridge University Press.

Nollenberger, N., N. Rodríguez-Planas, and Sevilla A. 2016. "The Math Gender Gap: The Role of Culture”, American Economic Review. Papers \& Proceedings, 106(5), pp. 257-61

OECD (2017a), PISA 2015 Technical Report, OECD Publishing, Paris

OECD (2017b), PISA 2015 Assessment and Analytical Framework: Science, Reading, Mathematics, Financial Literacy and Collaborative Problem Solving, revised edition, PISA, OECD Publishing, Paris.

Pope, D.G. and J.R Sydnor. 2010. "Geograhic Variation in the Gender Differences in Test Scores" Journal of Economic Perspectives, 24(2), pp. 95-108.

Rodríguez-Planas, N. and N. Nollenberger. 2018. "Let the Girls Learn! It it not only about Math, it is About Social Norms." Economics of Education Review, vol. 62, pp.230-253. 
Rodríguez-Planas, N. and A. Sanz-de-Galdeano. 2019. Intergenerational Transmission of Gender Social Norms and Teenage Smoking. Social Science \& Medicine, 222: 122-132.

World Economic Forum. 2018. The Global Gender Gap Report. Available at https://www.weforum.org/reports/the-global-gender-gap-report-2018.

Zanella, G. and Bellani, M. (2019). The Volatility of Survey Measures of Culture and Its Consequences, IZA Discussion Paper No. 12730. 


\section{APPENDIX}

Figure A1

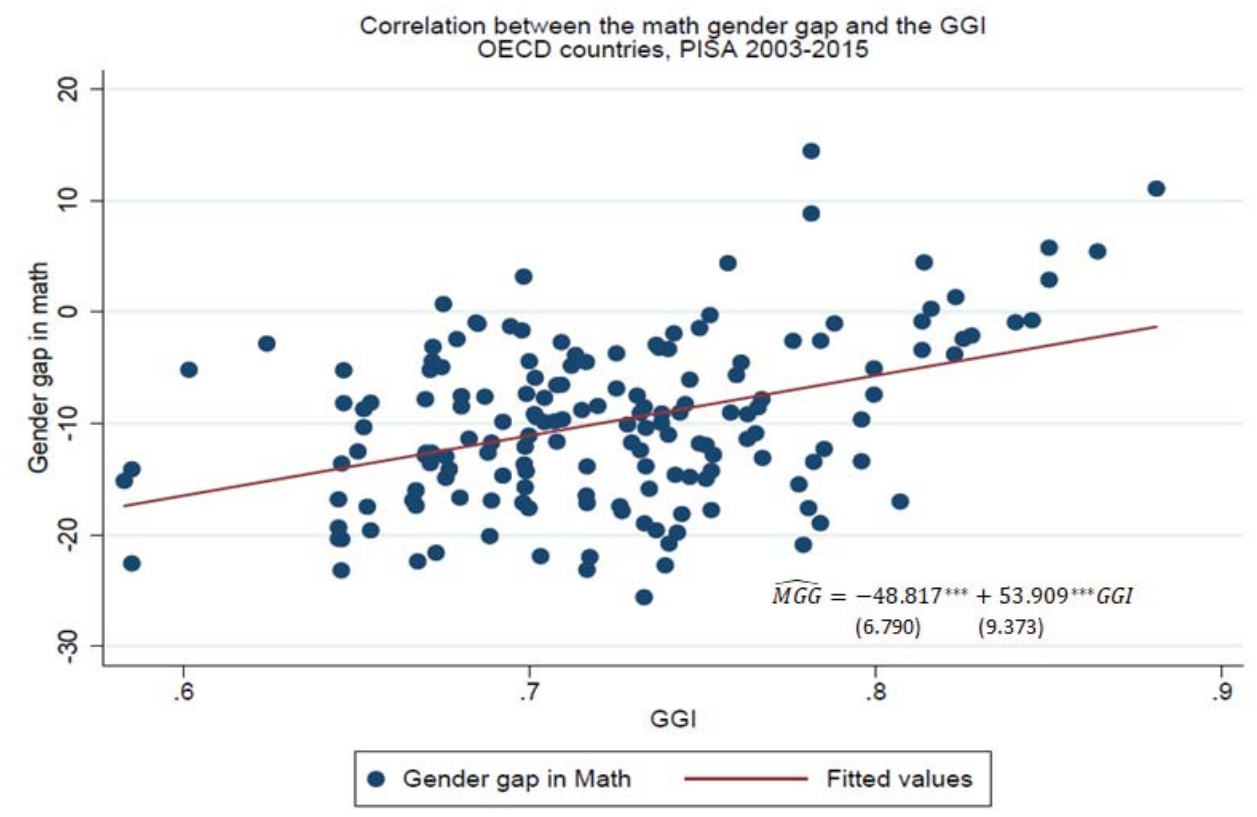

Notes:

*** $p<0.01,{ }^{* *} p<0.05,{ }^{*} p<0.1$

PISA sample of students above the median of the ESCS of each country.

Figure A2

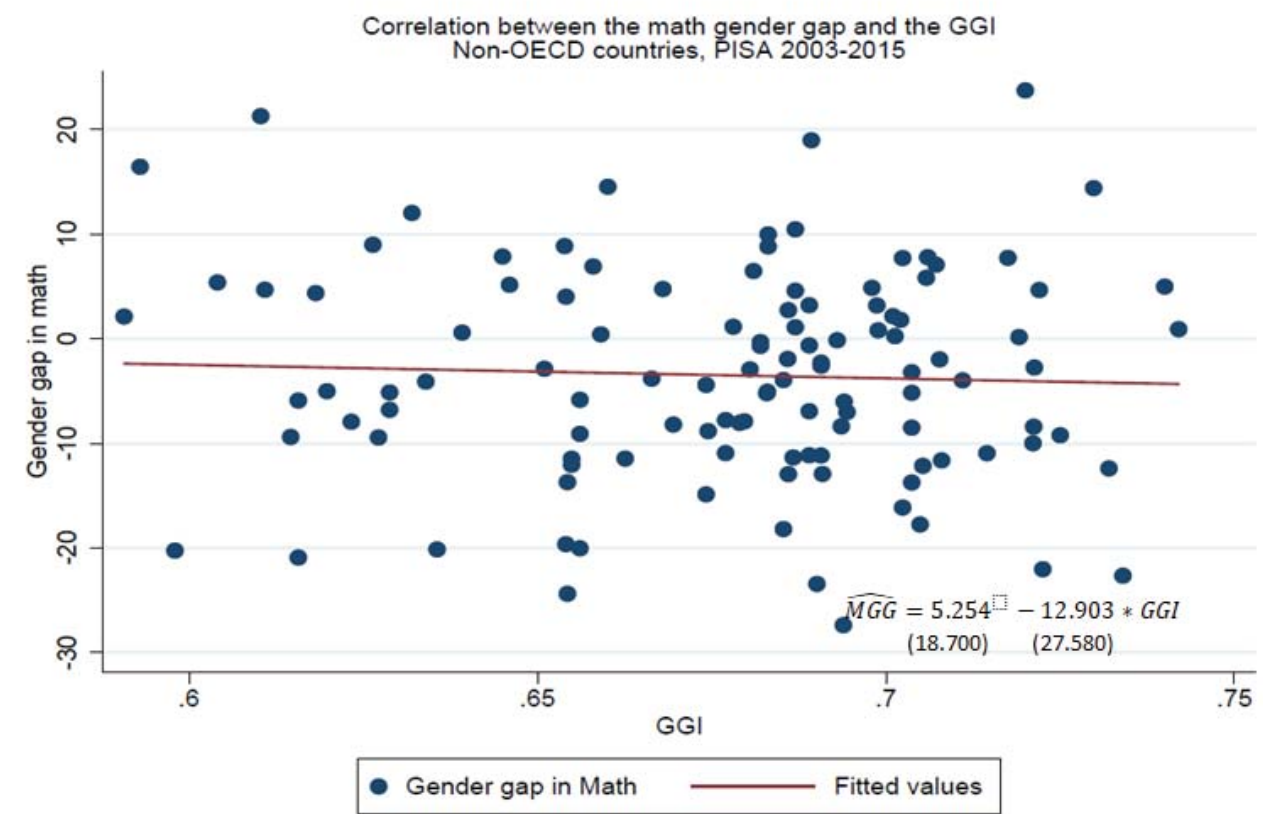

Notes:

*** $p<0.01,{ }^{* *} p<0.05,{ }^{*} p<0.1$

PISA sample of students above the median of the ESCS of each country. 
Figure A3

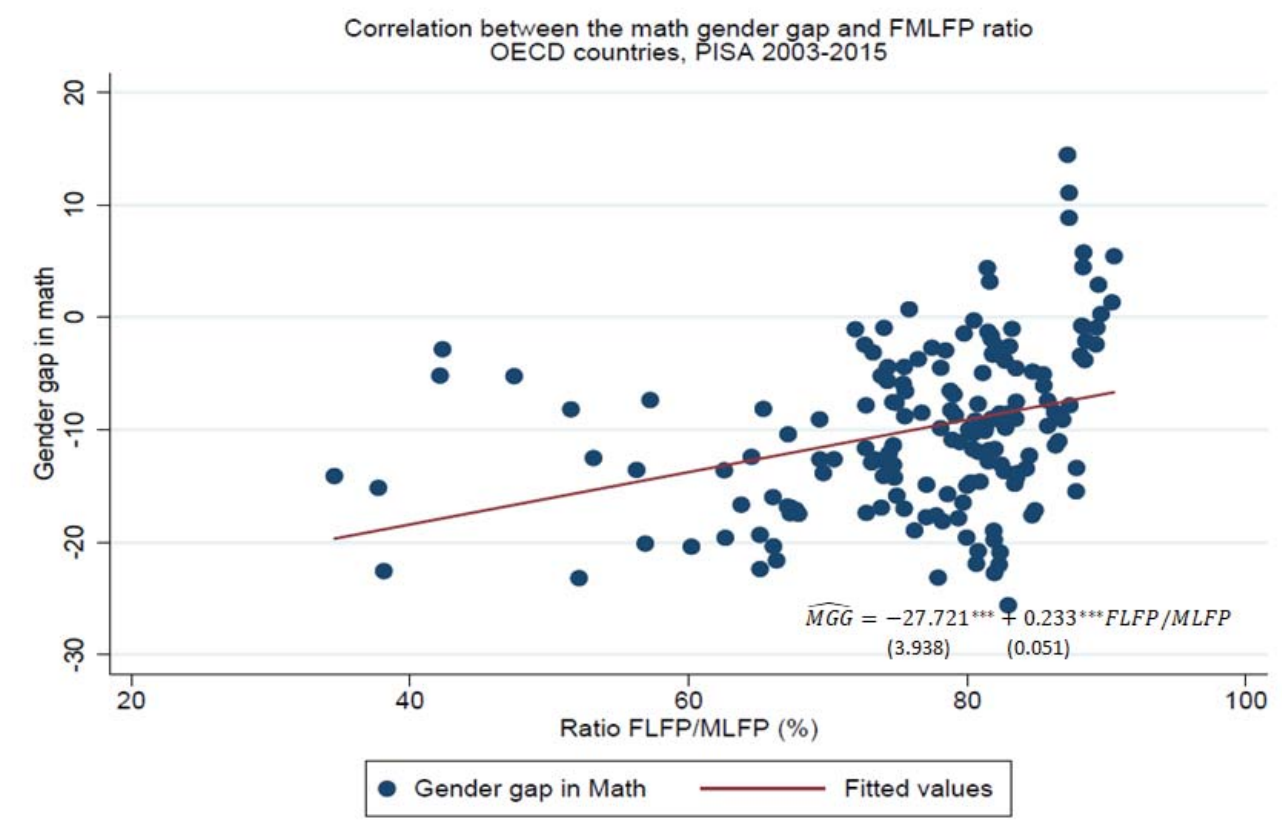

Notes:

*** $p<0.01,{ }^{* *} p<0.05,{ }^{*} p<0.1$

PISA sample of students above the median of the ESCS of each country.

Figure A4

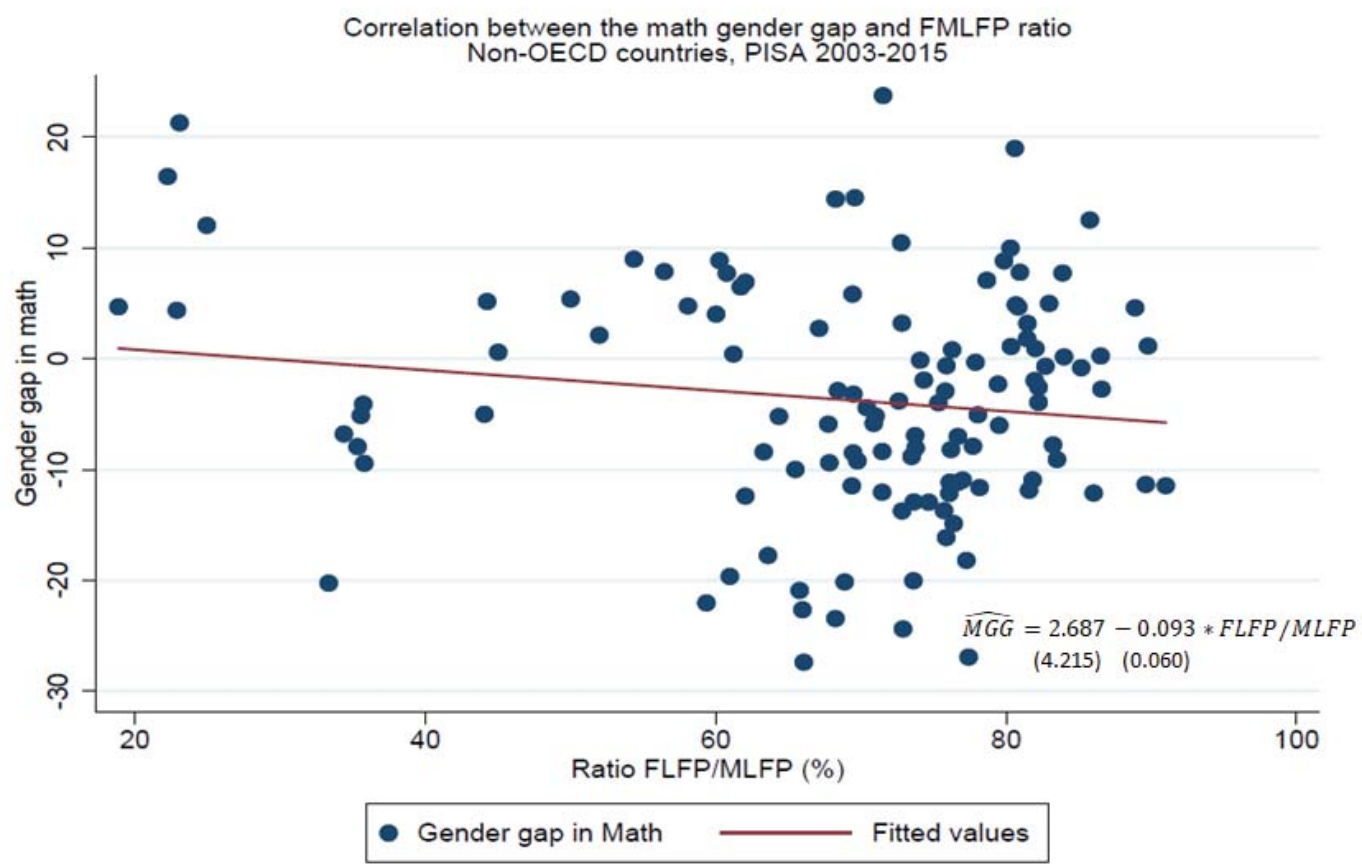

Notes:

*** $p<0.01,{ }^{* *} \mathrm{p}<0.05,{ }^{*} \mathrm{p}<0.1$

PISA sample of students above the median of the ESCS of each country. 
Table A1

Average gender gap and averages of gender equality measures

\begin{tabular}{|c|c|c|c|c|c|c|}
\hline Country & Years in PISA & $\begin{array}{l}\text { Average math } \\
\text { gender gap }\end{array}$ & $\begin{array}{c}\text { Average } \\
\text { reading } \\
\text { gender gap }\end{array}$ & $\begin{array}{l}\text { Gender Gap } \\
\text { Index }\end{array}$ & $\begin{array}{c}\text { Female/Male labour } \\
\text { force participation rate } \\
(\%)\end{array}$ & GDP pc in PPP \\
\hline \multicolumn{7}{|l|}{$O E C D$ countries } \\
\hline Australia & 2003/06/09/12/15 & $-10,26$ & 33,06 & 0,72 & 80,67 & $40.816,8$ \\
\hline Austria & $2003 / 06 / 09 / 12 / 15$ & $-19,61$ & 36,64 & 0,71 & 79,70 & $42.593,8$ \\
\hline Belgium & 2003/06/09/12/15 & $-13,00$ & 28,23 & 0,73 & 77,31 & $40.352,4$ \\
\hline Canada & 2003/06/09/12/15 & $-11,90$ & 31,09 & 0,73 & 85,62 & $40.942,2$ \\
\hline Chile & 2006/09/12/15 & $-20,69$ & 20,10 & 0,67 & 60,45 & $20.076,2$ \\
\hline Czech Rep. & $2003 / 06 / 09 / 12 / 15$ & $-8,49$ & 40,27 & 0,68 & 74,00 & $27.429,8$ \\
\hline Denmark & 2003/06/09/12/15 & $-11,10$ & 28,03 & 0,76 & 86,07 & $44.401,7$ \\
\hline Estonia & 2006/09/12/15 & $-3,49$ & 42,80 & 0,71 & 81,07 & $25.126,8$ \\
\hline Finland & 2003/06/09/12/15 & $-4,08$ & 48,78 & 0,82 & 87,88 & $39.034,6$ \\
\hline France & 2003/06/09/12/15 & $-11,24$ & 34,34 & 0,70 & 81,51 & $36.815,1$ \\
\hline Germany & 2003/06/09/12/15 & $-14,06$ & 36,44 & 0,76 & 78,71 & $40.302,2$ \\
\hline Greece & 2003/06/09/12/15 & $-11,66$ & 42,78 & 0,67 & 67,54 & $27.629,1$ \\
\hline Hungary & 2003/06/09/12/15 & $-8,17$ & 35,87 & 0,67 & 73,59 & $22.571,7$ \\
\hline Iceland & 2003/06/09/12/15 & 7,55 & 51,08 & 0,83 & 88,16 & $39.745,3$ \\
\hline Ireland & 2003/06/09/12/15 & $-13,17$ & 28,66 & 0,76 & 72,55 & $49.267,3$ \\
\hline Israel & 2006/09/12/15 & $-10,06$ & 36,48 & 0,70 & 82,83 & $29.648,7$ \\
\hline Italy & 2003/06/09/12/15 & $-17,93$ & 35,88 & 0,67 & 64,02 & $36.103,4$ \\
\hline Japan & 2003/06/09/12/15 & $-17,32$ & 21,84 & 0,65 & 67,12 & $35.795,6$ \\
\hline Latvia & 2003/06/09/12/15 & $-1,40$ & 46,67 & 0,73 & 79,97 & $19.298,4$ \\
\hline Luxembourg & 2003/06/09/12/15 & $-15,67$ & 32,09 & 0,70 & 74,18 & $90.202,7$ \\
\hline Mexico & 2003/06/09/12/15 & $-9,36$ & 26,05 & 0,66 & 53,13 & $15.678,1$ \\
\hline Netherlands & 2003/06/09/12/15 & $-6,70$ & 25,94 & 0,75 & 80,41 & $44.768,0$ \\
\hline New Zealand & 2003/06/09/12/15 & $-11,79$ & 33,36 & 0,77 & 82,56 & $32.654,5$ \\
\hline Norway & 2003/06/09/12/15 & $-2,85$ & 45,02 & 0,82 & 87,66 & $62.570,8$ \\
\hline Poland & 2003/06/09/12/15 & $-7,02$ & 38,94 & 0,70 & 75,31 & $20.704,5$ \\
\hline Portugal & 2003/06/09/12/15 & $-10,20$ & 33,38 & 0,70 & 81,39 & $26.417,3$ \\
\hline Slovak Rep. & 2003/06/09/12/15 & $-7,88$ & 42,65 & 0,68 & 75,16 & $23.594,9$ \\
\hline Slovenia & 2006/09/12/15 & $-2,04$ & 50,03 & 0,72 & 82,11 & $28.477,4$ \\
\hline Spain & 2003/06/09/12/15 & $-13,96$ & 29,48 & 0,73 & 73,82 & $32.298,3$ \\
\hline Sweden & 2003/06/09/12/15 & 0,38 & 42,32 & 0,82 & 88,94 & $42.264,0$ \\
\hline Switzerland & 2003/06/09/12/15 & $-14,77$ & 33,48 & 0,74 & 81,21 & $54.220,8$ \\
\hline Turkey & 2003/06/09/12/15 & $-11,96$ & 36,18 & 0,60 & 38,98 & $18.343,9$ \\
\hline United Kingdom & 2003/06/09/12/15 & $-12,26$ & 26,77 & 0,74 & 80,87 & $36.795,5$ \\
\hline United States of America & 2003/06/09/12/15 & $-9,22$ & 27,28 & 0,72 & 81,48 & $49.945,3$ \\
\hline \multicolumn{7}{|l|}{ Non-OECD countries } \\
\hline Albania & 2009 & 14,54 & 66,47 & 0,66 & 69,57 & $9.524,6$ \\
\hline Algeria & 2015 & 12,04 & 34,81 & 0,63 & 24,94 & $13.724,3$ \\
\hline Azerbaijan & 2006/09 & $-5,14$ & 23,22 & 0,67 & 90,37 & $13.052,5$ \\
\hline Argentina & 2006/09/12/15 & $-11,56$ & 38,51 & 0,71 & 64,77 & $18.021,7$ \\
\hline Brazil & 2003/06/09/12/15 & $-14,42$ & 31,34 & 0,67 & 74,62 & $13.524,9$ \\
\hline Bulgaria & 2006/09/12/15 & 3,67 & 58,36 & 0,70 & 80,31 & $15.396,8$ \\
\hline China & 2006/09/12/15 & $-4,07$ & 28,54 & 0,68 & 82,66 & $9.944,6$ \\
\hline Colombia & 2006/09/12/15 & $-19,44$ & 20,41 & 0,70 & 66,91 & $11.296,4$ \\
\hline Costa Rica & 2012/15 & $-17,21$ & 24,26 & 0,73 & 60,69 & $14.396,1$ \\
\hline Croatia & 2006/09/12/15 & $-10,43$ & 45,68 & 0,71 & 76,97 & $20.463,3$ \\
\hline Dominican Rep. & 2015 & 2,75 & 32,88 & 0,69 & 67,11 & $13.371,5$ \\
\hline Georgia & 2015 & 10,47 & 56,43 & 0,69 & 72,76 & $9.025,1$ \\
\hline Hong Kong-China & 2003/06/09/12/15 & $-11,10$ & 28,17 & 0,67 & 75,25 & $45.646,8$ \\
\hline Indonesia & 2003/06/09/12/15 & $-0,35$ & 29,11 & 0,66 & 61,19 & $8.217,1$ \\
\hline Kazakhstan & 2009/12 & $-1,24$ & 37,84 & 0,71 & 86,53 & $20.491,6$ \\
\hline Jordan & 2006/09/12/15 & 11,71 & 62,74 & 0,61 & 21,76 & $9.090,8$ \\
\hline Rep. of Korea & 2003/06/09/12/15 & $-11,84$ & 29,20 & 0,63 & 67,72 & $28.968,8$ \\
\hline Kyrgyzstan & 2006/09 & 0,72 & 50,93 & 0,69 & 69,90 & $2.627,3$ \\
\hline Lebanon & 2015 & $-20,25$ & 21,03 & 0,60 & 33,34 & $13.087,4$ \\
\hline Lithuania & $2006 / 09 / 12 / 15$ & 2,74 & 53,09 & 0,72 & 83,19 & $22.884,7$ \\
\hline Macao-China & 2003/06/09/12/15 & $-7,84$ & 28,45 & & 83,18 & $85.104,3$ \\
\hline Malaysia & 2012 & 8,87 & 39,66 & 0,65 & 60,25 & $22.591,0$ \\
\hline Malta & 2015 & 4,76 & 43,88 & 0,67 & 58,07 & $34.380,1$ \\
\hline Montenegro & 2006/09/12/15 & $-3,87$ & 49,59 & 0,69 & 82,01 & $13.859,6$ \\
\hline Rep. of Moldova & 2015 & 0,92 & 50,92 & 0,74 & 74,63 & $4.746,8$ \\
\hline Panama & 2009 & 7,73 & 48,40 & 0,70 & 60,75 & $14.838,6$ \\
\hline Peru & 2009/12/15 & $-12,02$ & 22,46 & 0,69 & 76,76 & $10.673,4$ \\
\hline Qatar & 2006/09/12/15 & 6,10 & 53,42 & 0,62 & 53,19 & $120.175,4$ \\
\hline Romania & 2006/09/12/15 & $-3,22$ & 37,80 & 0,68 & 75,47 & $18.153,8$ \\
\hline Russian Federation & 2003/06/09/12/15 & $-3,33$ & 36,90 & 0,69 & 81,33 & $21.782,9$ \\
\hline Serbia & 2003/06/09/12 & $-7,64$ & 42,39 & 0,70 & 70,68 & $11.591,0$ \\
\hline Singapore & 2009/12/15 & $-2,32$ & 26,98 & 0,69 & 74,73 & $73.536,4$ \\
\hline Viet Nam & 2012/15 & $-3,37$ & 26,60 & 0,69 & 89,24 & $5.288,9$ \\
\hline Thailand & 2003/06/09/12/15 & 8,67 & 46,78 & 0,69 & 80,22 & $12.972,6$ \\
\hline Trinidad and Tobago & $2009 / 15$ & 19,08 & 60,18 & 0,72 & 69,88 & $30.843,6$ \\
\hline United Arab Emirates & 2009/12/15 & 0,26 & 47,65 & 0,64 & 44,44 & $62.302,4$ \\
\hline Tunisia & 2003/06/09/12/15 & $-6,67$ & 36,02 & 0,63 & 35,35 & $9.733,5$ \\
\hline FYR Macedonia & 2015 & 2,17 & 40,02 & 0,70 & . & $12.759,7$ \\
\hline Uruguay & 2003/06/09/12/15 & $-9,74$ & 40,20 & 0,67 & 71,90 & $15.838,9$ \\
\hline Total no. of countries & 73 & 73 & 73 & 72 & 72 & 73 \\
\hline Average & & $-7,4$ & 36,8 & 0,7 & 73,4 & $31.939,0$ \\
\hline Standard deviation & & 9,2 & 11,7 & 0,1 & 13,6 & $21.322,2$ \\
\hline
\end{tabular}


Table A2. Gender gap in PISA Math test and gender equality measures. PISA sample of all students Pooled cross-sectional analysis

\begin{tabular}{|c|c|c|c|c|c|c|}
\hline Panel A. Guiso et al. (2008) sample & (1) & $(2)$ & (3) & (4) & (5) & (6) \\
\hline GGI & $\begin{array}{c}65.420 * * * \\
(14.743)\end{array}$ & & & & & \\
\hline Econ. index & & $\begin{array}{c}33.877^{* * *} \\
(8.862)\end{array}$ & & & & \\
\hline PEI & & & $\begin{array}{c}18.749 * * * \\
(5.531)\end{array}$ & & & \\
\hline Educ. index & & & & $\begin{array}{l}38.704 * \\
(21.853)\end{array}$ & & \\
\hline Health index & & & & & $\begin{array}{c}-29.313 \\
(64.136)\end{array}$ & \\
\hline FMLFP ratio & & & & & & $\begin{array}{c}0.227^{* *} \\
(0.088)\end{array}$ \\
\hline Log of GDP pc in PPP & $\begin{array}{c}-6.194 * * * \\
(1.523)\end{array}$ & $\begin{array}{c}-5.178^{* * *} \\
(1.440)\end{array}$ & $\begin{array}{c}-4.991 * * * \\
(1.526)\end{array}$ & $\begin{array}{l}-3.006 \\
(1.829)\end{array}$ & $\begin{array}{l}-2.494 \\
(1.727)\end{array}$ & $\begin{array}{c}-4.411 * * \\
(1.915)\end{array}$ \\
\hline Constant & $\begin{array}{c}7.336 \\
(14.318)\end{array}$ & $\begin{array}{c}20.991 \\
(13.393)\end{array}$ & $\begin{array}{c}37.439 * * \\
(15.811)\end{array}$ & $\begin{array}{c}-17.088 \\
(21.465)\end{array}$ & $\begin{array}{c}44.514 \\
(62.285)\end{array}$ & $\begin{array}{c}18.823 \\
(16.202)\end{array}$ \\
\hline R-squared & $\begin{array}{c}0.228 \\
184\end{array}$ & $\begin{array}{c}0.195 \\
184\end{array}$ & $\begin{array}{c}0.164 \\
184\end{array}$ & $\begin{array}{c}0.045 \\
184\end{array}$ & $\begin{array}{c}0.037 \\
184\end{array}$ & $\begin{array}{c}0.112 \\
199\end{array}$ \\
\hline No. of countries & 37 & 37 & 37 & 37 & 37 & 40 \\
\hline Panel B. OECD countries & & & & & & \\
\hline GGI & $\begin{array}{c}69.040 * * * \\
(14.618)\end{array}$ & & & & & \\
\hline Econ. index & & $\begin{array}{c}36.967 * * * \\
(9.383)\end{array}$ & & & & \\
\hline PEI & & & $\begin{array}{c}20.200 * * * \\
(5.384)\end{array}$ & & & \\
\hline Educ. index & & & & $\begin{array}{c}29.851 \\
(22.759)\end{array}$ & & \\
\hline Health index & & & & & $\begin{array}{l}-281.517 \\
(302.448)\end{array}$ & \\
\hline FMLFP ratio & & & & & & $\begin{array}{c}0.295^{* *} \\
(0.117)\end{array}$ \\
\hline Log of GDP pc in PPP & $\begin{array}{c}-6.992 * * * \\
(1.829)\end{array}$ & $\begin{array}{c}-6.992 * * * \\
(1.829)\end{array}$ & $\begin{array}{c}-6.190 * * * \\
(1.500)\end{array}$ & $\begin{array}{c}-5.184 * * \\
(2.147)\end{array}$ & $\begin{array}{l}-2.255 \\
(2.695)\end{array}$ & $\begin{array}{c}-5.573 * * \\
(2.086)\end{array}$ \\
\hline Constant & $\begin{array}{c}12.899 \\
(18.827)\end{array}$ & $\begin{array}{l}29.532^{*} \\
(16.415)\end{array}$ & $\begin{array}{l}38.875^{*} \\
(22.207)\end{array}$ & $\begin{array}{l}-16.269 \\
(25.206)\end{array}$ & $\begin{array}{c}290.723 \\
(299.447)\end{array}$ & $\begin{array}{c}29.510 \\
(17.924)\end{array}$ \\
\hline R-squared & 0.238 & 0.197 & 0.173 & 0.015 & 0.030 & 0.162 \\
\hline Observations & 166 & 166 & 166 & 166 & 166 & 166 \\
\hline No. of countries & 34 & 34 & 34 & 34 & 34 & 34 \\
\hline Panel C. Non-OECD countries & & & & & & \\
\hline GGI & $\begin{array}{c}-21.463 \\
(52.637)\end{array}$ & & & & & \\
\hline Econ. index & & $\begin{array}{c}5.082 \\
(18.459)\end{array}$ & & & & \\
\hline PEI & & & $\begin{array}{c}-31.754 \\
(18.973)\end{array}$ & & & \\
\hline Educ. index & & & & $\begin{array}{c}33.830 \\
(53.134)\end{array}$ & & \\
\hline Health index & & & & & $\begin{array}{c}-44.096 \\
(89.265)\end{array}$ & \\
\hline FMLFP ratio & & & & & & $\begin{array}{l}-0.086 \\
(0.110)\end{array}$ \\
\hline Log of GDP pc in PPP & $\begin{array}{c}2.462 \\
(2.156)\end{array}$ & $\begin{array}{c}2.658 \\
(2.301)\end{array}$ & $\begin{array}{c}2.228 \\
(1.923)\end{array}$ & $\begin{array}{c}2.614 \\
(2.164)\end{array}$ & $\begin{array}{c}2.440 \\
(2.111)\end{array}$ & $\begin{array}{c}2.194 \\
(1.812)\end{array}$ \\
\hline Constant & $\begin{array}{c}-13.962 \\
(45.601)\end{array}$ & $\begin{array}{l}-33.617 \\
(27.636)\end{array}$ & $\begin{array}{c}-22.235 \\
(19.680)\end{array}$ & $\begin{array}{l}-63.228 \\
(55.109)\end{array}$ & $\begin{array}{c}14.432 \\
(84.037)\end{array}$ & $\begin{array}{c}-20.314 \\
(19.901)\end{array}$ \\
\hline R-squared & 0.038 & 0.035 & 0.078 & 0.036 & 0.037 & 0.042 \\
\hline Observations & 117 & 117 & 117 & 117 & 117 & 121 \\
\hline No. of countries & 38 & 38 & 38 & 38 & 38 & 38 \\
\hline
\end{tabular}

Notes: Standard errors clustered at country level in parentheses

$* * * p<0.01, * * p<0.05, * p<0.1$ 
Table A3. Gender gap in PISA Math test and gender equality measures. PISA sample of all students Pooled cross-sectional analysis with year fixed effects

\begin{tabular}{|c|c|c|c|c|c|c|}
\hline Panel A. Guiso et al. (2008) sample & (1) & (2) & (3) & (4) & (5) & (6) \\
\hline GGI & $\begin{array}{c}64.460 * * * \\
(15.884)\end{array}$ & & & & & \\
\hline Econ. index & & $\begin{array}{c}33.304 * * * \\
(9.564)\end{array}$ & & & & \\
\hline PEI & & & $\begin{array}{c}18.174 * * * \\
(5.778)\end{array}$ & & & \\
\hline Educ. index & & & & $\begin{array}{c}32.287 \\
(21.589)\end{array}$ & & \\
\hline Health index & & & & & $\begin{array}{c}-25.265 \\
(65.154)\end{array}$ & \\
\hline FMLFP ratio & & & & & & $\begin{array}{c}0.222^{* *} \\
(0.088)\end{array}$ \\
\hline Log of GDP pc in PPP & $\begin{array}{c}-6.168^{* * *} \\
(1.548)\end{array}$ & $\begin{array}{c}-5.144^{* * *} \\
(1.464)\end{array}$ & $\begin{array}{c}-5.018 * * * \\
(1.557)\end{array}$ & $\begin{array}{l}-3.061 \\
(1.859)\end{array}$ & $\begin{array}{l}-2.654 \\
(1.763)\end{array}$ & $\begin{array}{c}-4.580 * * \\
(1.912)\end{array}$ \\
\hline Constant & $\begin{array}{c}8.419 \\
(14.635)\end{array}$ & $\begin{array}{c}21.783 \\
(13.601)\end{array}$ & $\begin{array}{c}38.160 * * \\
(16.041)\end{array}$ & $\begin{array}{l}-10.006 \\
(21.697)\end{array}$ & $\begin{array}{c}42.278 \\
(63.166)\end{array}$ & $\begin{array}{c}20.716 \\
(16.307)\end{array}$ \\
\hline R-squared & $\begin{array}{c}0.242 \\
184\end{array}$ & $\begin{array}{c}0.208 \\
184\end{array}$ & $\begin{array}{c}0.184 \\
184\end{array}$ & $\begin{array}{c}0.072 \\
184\end{array}$ & $\begin{array}{c}0.067 \\
184\end{array}$ & $\begin{array}{c}0.153 \\
199\end{array}$ \\
\hline No. of countries & 37 & 37 & 37 & 37 & 37 & 40 \\
\hline Panel B. OECD countries & & & & & & \\
\hline GGI & $\begin{array}{c}70.187^{* * * *} \\
(16.370)\end{array}$ & & & & & \\
\hline Econ. index & & $\begin{array}{c}38.495^{* * *} \\
(10.990)\end{array}$ & & & & \\
\hline PEI & & & $\begin{array}{c}19.744^{* * *} \\
(5.707)\end{array}$ & & & \\
\hline Educ. index & & & & $\begin{array}{c}24.945 \\
(22.609)\end{array}$ & & \\
\hline Health index & & & & & $\begin{array}{l}-273.665 \\
(306.857)\end{array}$ & \\
\hline FMLFP ratio & & & & & & $\begin{array}{c}0.295^{* *} \\
(0.122)\end{array}$ \\
\hline Log of GDP pc in PPP & $\begin{array}{c}-7.084^{* * *} \\
(1.856)\end{array}$ & $\begin{array}{c}-6.348 * * * \\
(1.505)\end{array}$ & $\begin{array}{c}-5.211 * * \\
(2.181)\end{array}$ & $\begin{array}{l}-2.354 \\
(2.735)\end{array}$ & $\begin{array}{l}-2.676 \\
(2.513)\end{array}$ & $\begin{array}{c}-6.087 * * * \\
(1.756)\end{array}$ \\
\hline Constant & $\begin{array}{c}14.119 \\
(18.773)\end{array}$ & $\begin{array}{l}31.511 * \\
(16.145)\end{array}$ & $\begin{array}{l}39.842 * \\
(22.301)\end{array}$ & $\begin{array}{c}-9.994 \\
(24.728)\end{array}$ & $\begin{array}{c}285.106 \\
(303.817)\end{array}$ & $\begin{array}{l}31.578 * \\
(18.047)\end{array}$ \\
\hline R-squared & 0.255 & 0.216 & 0.189 & 0.041 & 0.057 & 0.186 \\
\hline Observations & 166 & 166 & 166 & 166 & 166 & 166 \\
\hline No. of countries & 34 & 34 & 34 & 34 & 34 & 34 \\
\hline Panel C. Non-OECD countries & & & & & & \\
\hline GGI & $\begin{array}{c}-39.592 \\
(54.453)\end{array}$ & & & & & \\
\hline Econ. index & & $\begin{array}{c}3.196 \\
(18.495)\end{array}$ & & & & \\
\hline PEI & & & $\begin{array}{c}-45.831 * * \\
(19.312)\end{array}$ & & & \\
\hline Educ. index & & & & $\begin{array}{c}20.897 \\
(51.508)\end{array}$ & & \\
\hline Health index & & & & & $\begin{array}{c}-46.692 \\
(88.612)\end{array}$ & \\
\hline FMLFP ratio & & & & & & $\begin{array}{l}-0.077 \\
(0.111)\end{array}$ \\
\hline Log of GDP pc in PPP & $\begin{array}{c}1.866 \\
(2.240)\end{array}$ & $\begin{array}{c}2.253 \\
(2.445)\end{array}$ & $\begin{array}{c}1.454 \\
(1.949)\end{array}$ & $\begin{array}{c}2.234 \\
(2.340)\end{array}$ & $\begin{array}{c}2.033 \\
(2.256)\end{array}$ & $\begin{array}{c}1.819 \\
(1.903)\end{array}$ \\
\hline Constant & $\begin{array}{c}-0.313 \\
(46.839)\end{array}$ & $\begin{array}{l}-32.000 \\
(27.927)\end{array}$ & $\begin{array}{c}-18.555 \\
(19.519)\end{array}$ & $\begin{array}{l}-50.172 \\
(56.842)\end{array}$ & $\begin{array}{c}17.292 \\
(82.680)\end{array}$ & $\begin{array}{l}-22.185 \\
(20.030)\end{array}$ \\
\hline R-squared & 0.098 & 0.083 & 0.168 & 0.084 & 0.087 & 0.101 \\
\hline Observations & 117 & 117 & 117 & 117 & 117 & 121 \\
\hline No. of countries & 38 & 38 & 38 & 38 & 38 & 38 \\
\hline
\end{tabular}

Notes: Standard errors clustered at country level in parentheses

$* * * p<0.01, * * p<0.05, * p<0.1$ 
Table A4. Gender gap in PISA Math test and gender equality measures. PISA sample of all students Panel analysis (with year and country fixed effects)

\begin{tabular}{|c|c|c|c|c|c|c|}
\hline Panel A. Guiso et al. (2008) sample & (1) & $(2)$ & (3) & (4) & (5) & (6) \\
\hline \multirow[t]{2}{*}{ GGI } & -26.115 & & & & & \\
\hline & $(27.438)$ & & & & & \\
\hline \multirow[t]{2}{*}{ Econ. index } & & $-33.900 * *$ & & & & \\
\hline & & $(12.570)$ & & & & \\
\hline \multirow[t]{2}{*}{ PEI } & & & 2.191 & & & \\
\hline & & & $(10.998)$ & & & \\
\hline \multirow[t]{2}{*}{ Educ. index } & & & & 34.295 & & \\
\hline & & & & $(34.748)$ & & \\
\hline \multirow[t]{2}{*}{ Health index } & & & & & -113.376 & \\
\hline & & & & & $(128.991)$ & \\
\hline \multirow[t]{2}{*}{ FMLFP ratio } & & & & & & -0.379 \\
\hline & & & & & & $(0.290)$ \\
\hline \multirow[t]{2}{*}{ Log of GDP pc in PPP } & 4.161 & 0.056 & 5.054 & 3.480 & 5.427 & 9.720 \\
\hline & $(6.594)$ & $(6.251)$ & $(6.562)$ & $(7.073)$ & $(6.556)$ & $(8.117)$ \\
\hline \multirow[t]{2}{*}{ Constant } & -33.411 & 11.645 & -61.113 & -78.459 & 46.049 & -81.428 \\
\hline & $(74.801)$ & $(67.150)$ & $(66.914)$ & (59.198) & $(141.722)$ & $(95.236)$ \\
\hline \multirow[t]{2}{*}{ R-squared } & 0.087 & 0.119 & 0.081 & 0.085 & 0.084 & 0.150 \\
\hline & 184 & 184 & 184 & 184 & 184 & 199 \\
\hline No. of countries & 37 & 37 & 37 & 37 & 37 & 40 \\
\hline \multicolumn{7}{|l|}{ Panel B. OECD countries } \\
\hline \multirow[t]{2}{*}{ GGI } & -23.238 & & & & & \\
\hline & $(25.475)$ & & & & & \\
\hline \multirow[t]{2}{*}{ Econ. index } & & $-27.241 * *$ & & & & \\
\hline & & $(12.982)$ & & & & \\
\hline \multirow[t]{2}{*}{ PEI } & & & -0.951 & & & \\
\hline & & & $(9.146)$ & & & \\
\hline \multirow[t]{2}{*}{ Educ. index } & & & & 34.927 & & \\
\hline & & & & (34.301) & & \\
\hline \multirow[t]{2}{*}{ Health index } & & & & & -182.162 & \\
\hline & & & & & $(146.643)$ & \\
\hline \multirow[t]{2}{*}{ FMLFP ratio } & & & & & & -0.425 \\
\hline & & & & & & $(0.270)$ \\
\hline Log of GDP pc in PPP & 3.728 & 0.856 & 4.245 & 2.561 & 5.332 & 0.783 \\
\hline & (7.881) & (7.655) & (7.989) & $(8.623)$ & $(8.247)$ & (7.962) \\
\hline Constant & -32.031 & -1.347 & -53.538 & -70.808 & 112.816 & 13.455 \\
\hline & $(88.628)$ & $(83.233)$ & $(82.882)$ & $(73.337)$ & $(136.820)$ & (87.295) \\
\hline R-squared & 0.083 & 0.103 & 0.078 & 0.082 & 0.083 & 0.106 \\
\hline Observations & 166 & 166 & 166 & 166 & 166 & 166 \\
\hline No. of countries & 34 & 34 & 34 & 34 & 34 & 34 \\
\hline Panel C. Non-OECD countries & & & & & & \\
\hline GGI & 28.606 & & & & & \\
\hline & $(44.403)$ & & & & & \\
\hline Econ. index & & 7.793 & & & & \\
\hline & & $(16.086)$ & & & & \\
\hline PEI & & & 4.101 & & & \\
\hline & & & $(16.804)$ & & & \\
\hline Educ. index & & & & -31.628 & & \\
\hline & & & & $(60.558)$ & & \\
\hline Health index & & & & & 193.017 & \\
\hline & & & & & $(140.096)$ & \\
\hline FMLFP ratio & & & & & & 0.402 \\
\hline & & & & & & $(0.300)$ \\
\hline Log of GDP pc in PPP & -1.027 & -0.455 & -0.622 & 0.449 & 0.779 & 8.005 \\
\hline & (7.609) & $(7.757)$ & $(7.407)$ & $(7.817)$ & $(8.950)$ & $(7.837)$ \\
\hline Constant & -15.096 & -6.297 & -0.325 & 20.813 & -199.971 & -110.364 \\
\hline & (77.958) & $(74.167)$ & $(70.008)$ & $(83.548)$ & $(184.924)$ & $(82.703)$ \\
\hline R-squared & 0.153 & 0.152 & 0.150 & 0.152 & 0.171 & 0.206 \\
\hline Observations & 117 & 117 & 117 & 117 & 117 & 121 \\
\hline No. of countries & 38 & 38 & 38 & 38 & 38 & 38 \\
\hline
\end{tabular}

Notes: Standard errors clustered at country level in parentheses

*** $p<0.01, * * p<0.05, * p<0.1$ 
Table A.5. Gender gap in PISA Math test and gender equality measures. Multivel model.

Panel analysis (with year and country fixed effects)

\begin{tabular}{|c|c|c|c|c|c|c|}
\hline Panel A. Guiso et al. (2008) sample & $(1)$ & (2) & (3) & (4) & (5) & (6) \\
\hline \multirow[t]{2}{*}{ GGI } & -12.831 & & & & & \\
\hline & $(26.620)$ & & & & & \\
\hline \multirow[t]{2}{*}{ Econ. index } & & -14.006 & & & & \\
\hline & & $(16.143)$ & & & & \\
\hline \multirow[t]{2}{*}{ PEI } & & & -1.213 & & & \\
\hline & & & $(9.029)$ & & & \\
\hline \multirow[t]{2}{*}{ Educ. index } & & & & 41.551 & & \\
\hline & & & & $(41.643)$ & & \\
\hline \multirow[t]{2}{*}{ Health index } & & & & & 19.906 & \\
\hline & & & & & $(145.303)$ & \\
\hline \multirow[t]{2}{*}{ FMLFP ratio } & & & & & & -0.283 \\
\hline & & & & & & $(0.229)$ \\
\hline \multirow[t]{2}{*}{ Log of GDP pc in PPP } & $11.448^{*}$ & 9.817 & $11.820^{*}$ & 10.025 & $11.779 *$ & $15.013^{* *}$ \\
\hline & $(6.167)$ & $(6.461)$ & $(6.035)$ & $(6.272)$ & $(5.830)$ & (7.199) \\
\hline \multirow[t]{2}{*}{ Constant } & $-120.130 *$ & -103.598 & $-132.621 * *$ & $-155.529 * *$ & -151.841 & $-145.719 *$ \\
\hline & $(70.473)$ & (71.108) & $(61.638)$ & $(57.603)$ & $(164.835)$ & $(84.971)$ \\
\hline R-squared & 0.100 & 0.105 & 0.099 & 0.104 & 0.099 & 0.159 \\
\hline Observations & 184 & 184 & 184 & 184 & 184 & 199 \\
\hline No. of countries & 37 & 37 & 37 & 37 & 37 & 40 \\
\hline \multicolumn{7}{|l|}{ Panel B. OECD countries } \\
\hline \multirow[t]{2}{*}{ GGI } & -13.542 & & & & & \\
\hline & $(23.215)$ & & & & & \\
\hline \multirow[t]{2}{*}{ Econ. index } & & -1.580 & & & & \\
\hline & & $(15.406)$ & & & & \\
\hline \multirow[t]{2}{*}{ PEI } & & & -5.471 & & & \\
\hline & & & (7.107) & & & \\
\hline \multirow[t]{2}{*}{ Educ. index } & & & & 36.285 & & \\
\hline & & & & $(40.765)$ & & \\
\hline \multirow[t]{2}{*}{ Health index } & & & & & 46.390 & \\
\hline & & & & & $(235.818)$ & \\
\hline \multirow[t]{2}{*}{ FMLFP ratio } & & & & & & $-0.306^{*}$ \\
\hline & & & & & & $(0.173)$ \\
\hline \multirow[t]{2}{*}{ Log of GDP pc in PPP } & 7.630 & 7.745 & 7.830 & 6.173 & 7.671 & 5.440 \\
\hline & $(7.045)$ & $(7.621)$ & $(6.905)$ & $(6.462)$ & $(6.614)$ & $(7.760)$ \\
\hline Constant & -82.339 & -92.059 & -92.756 & -112.627 & -137.579 & -46.671 \\
\hline & $(79.266)$ & $(83.925)$ & $(71.610)$ & $(71.100)$ & $(247.742)$ & $(86.878)$ \\
\hline R-squared & 0.063 & 0.062 & 0.065 & 0.066 & 0.062 & 0.077 \\
\hline Observations & 166 & 166 & 166 & 166 & 166 & 166 \\
\hline No. of countries & 34 & 34 & 34 & 34 & 34 & 34 \\
\hline Panel C. Non-OECD countries & & & & & & \\
\hline GGI & 36.413 & & & & & \\
\hline & (52.559) & & & & & \\
\hline Econ. index & & -4.225 & & & & \\
\hline & & $(14.059)$ & & & & \\
\hline PEI & & & 27.421 & & & \\
\hline & & & $(24.993)$ & & & \\
\hline Educ. index & & & & 8.363 & & \\
\hline & & & & $(59.483)$ & & \\
\hline Health index & & & & & 50.646 & \\
\hline & & & & & $(111.241)$ & \\
\hline FMLFP ratio & & & & & & 0.038 \\
\hline & & & & & & $(0.390)$ \\
\hline Log of GDP pc in PPP & -9.194 & -8.333 & -9.979 & -8.596 & -8.079 & 2.902 \\
\hline & (7.231) & (7.017) & $(6.900)$ & (7.368) & (7.569) & (9.695) \\
\hline Constant & 52.665 & 71.317 & 81.552 & 63.047 & 17.270 & -42.109 \\
\hline & $(65.430)$ & $(63.496)$ & (64.569) & $(72.106)$ & $(164.227)$ & $(106.539)$ \\
\hline R-squared & 0.197 & 0.193 & 0.207 & 0.193 & 0.194 & 0.215 \\
\hline Observations & 115 & 115 & 115 & 115 & 115 & 119 \\
\hline No. of countries & 38 & 38 & 38 & 38 & 38 & 38 \\
\hline
\end{tabular}

Notes: PISA sample of students above the median of ESCS of each country

Standard errors clustered at country level in parentheses

$* * * p<0.01, * * p<0.05, * p<0.1$

In Level 1, we estimate separate equations for each country $i$ and year $j$ across students. The dependent variable is PISA score and control variables are: a dummy for female, a dummy for different grade, age, level of education and employment status of parents

In Level 2, the coefficient of the female dummy from Level 1 is regressed on country and year level variables, and year and country fixed effects. 
Table A.6. Gender gap in Math. Tests of sum of coefficients from estimation of multilevel model with nonlinearities

\begin{tabular}{|c|c|c|}
\hline & $\begin{array}{l}\text { Estimation of sample of } \\
\text { students above the median of } \\
\text { ESCS of each country }\end{array}$ & $\begin{array}{c}\text { Estimation of sample of } \\
\text { all students }\end{array}$ \\
\hline & Summ of coeff. & Summ of coeff. \\
\hline \multirow[t]{2}{*}{$\mathrm{GGI}+\mathrm{Q} 1 * \mathrm{GGI}$} & $108.531^{* * *}$ & $98.871^{* * *}$ \\
\hline & $(40,874)$ & $(34,496)$ \\
\hline \multirow[t]{2}{*}{$\mathrm{EOI}+\mathrm{Q} 1 * \mathrm{EOI}$} & 5.896 & 13.565 \\
\hline & $(21,733)$ & $(19,714)$ \\
\hline \multirow[t]{2}{*}{$\mathrm{PEI}+\mathrm{Q} 1 * \mathrm{PEI}$} & $61.267^{* * *}$ & $40.289^{* *}$ \\
\hline & $(21,935)$ & $(19,347)$ \\
\hline \multirow[t]{2}{*}{ Educ.index + Q1 * Educ.index } & $112.060 * *$ & $90.584^{* * *}$ \\
\hline & $(43,956)$ & $(33,557)$ \\
\hline \multirow[t]{2}{*}{ Health index $+Q 1 *$ Health index } & $265.155^{*}$ & $345.962 * * *$ \\
\hline & $(154,822)$ & $(90,351)$ \\
\hline \multirow[t]{2}{*}{ FMLFP ratio + Q1 * FMLFP ratio } & -0.092 & 0.041 \\
\hline & $(0,158)$ & $(0,149)$ \\
\hline
\end{tabular}

Notes: Standard errors in parentheses.

*** $p<0.01,{ }^{* *} p<0.05,{ }^{*} p<0.1$

Table A.7. Gender gap in Reading. Tests of sum of coefficients from estimation of the model with nonlinearities

\begin{tabular}{|c|c|c|}
\hline & $\begin{array}{l}\text { Estimation of sample of } \\
\text { students above the median of } \\
\text { ESCS of each country }\end{array}$ & $\begin{array}{c}\text { Estimation of sample of } \\
\text { all students }\end{array}$ \\
\hline & Summ of coeff. & Summ of coeff. \\
\hline \multirow[t]{2}{*}{$\mathrm{GGI}+\mathrm{Q} 1 * \mathrm{GGI}$} & 14.659 & 84.913 \\
\hline & $(77,955)$ & $(87,650)$ \\
\hline \multirow[t]{2}{*}{$\mathrm{EOI}+\mathrm{Q} 1 * \mathrm{EOI}$} & -27.900 & -27.948 \\
\hline & $(38,411)$ & $(39,182)$ \\
\hline \multirow[t]{2}{*}{$\mathrm{PEI}+\mathrm{Q} 1$ * PEI } & 6.505 & 47.978 \\
\hline & $(32,501)$ & $(36,345)$ \\
\hline \multirow[t]{2}{*}{ Educ.index + Q1 * Educ.index } & $186.669 * * *$ & 85.559 \\
\hline & $(44,531)$ & $(58,241)$ \\
\hline \multirow[t]{2}{*}{ Health index + Q1 * Health index } & -132.221 & 653.211 \\
\hline & $(248,924)$ & $(493,509)$ \\
\hline \multirow[t]{2}{*}{ FMLFP ratio + Q1 * FMLFP ratio } & -0.078 & 0.040 \\
\hline & $(0,315)$ & $(0,258)$ \\
\hline
\end{tabular}

Notes: Standard errors in parentheses.

$* * * p<0.01, * * p<0.05, * p<0.1$ 


\section{BANCO DE ESPAÑA PUBLICATIONS}

\section{WORKING PAPERS}

1930 MICHAEL FUNKE, DANILO LEIVA-LEON and ANDREW TSANG: Mapping China's time-varying house price landscape.

1931 JORGE E. GALÁN and MATÍAS LAMAS: Beyond the LTV ratio: new macroprudential lessons from Spain.

1932 JACOPO TIMINI: Staying dry on Spanish wine: the rejection of the 1905 Spanish-Italian trade agreement.

1933 TERESA SASTRE and LAURA HERAS RECUERO: Domestic and foreign investment in advanced economies. The role of industry integration.

1934 DANILO LEIVA-LEON, JAIME MARTÍNEZ-MARTÍN and EVA ORTEGA: Exchange rate shocks and inflation comovement in the euro area.

1935 FEDERICO TAGLIATI: Child labor under cash and in-kind transfers: evidence from rural Mexico.

1936 ALBERTO FUERTES: External adjustment with a common currency: the case of the euro area.

1937 LAURA HERAS RECUERO and ROBERTO PASCUAL GONZÁLEZ: Economic growth, institutional quality and financial development in middle-income countries.

1938 SILVIA ALBRIZIO, SANGYUP CHOI, DAVIDE FURCERI and CHANSIK YOON: International Bank Lending Channel of Monetary Policy.

1939 MAR DELGADO-TÉLLEZ, ENRIQUE MORAL-BENITO and JAVIER J. PÉREZ: Outsourcing and public expenditure: an aggregate perspective with regional data.

1940 MYROSLAV PIDKUYKO: Heterogeneous spillovers of housing credit policy.

1941 LAURA ÁLVAREZ ROMÁN and MIGUEL GARCÍA-POSADA GÓMEZ: Modelling regional housing prices in Spain.

1942 STÉPHANE DÉES and ALESSANDRO GALESI: The Global Financial Cycle and US monetary policy in an interconnected world.

1943 ANDRÉS EROSA and BEATRIZ GONZÁLEZ: Taxation and the life cycle of firms.

1944 MARIO ALLOZA, JESÚS GONZALO and CARLOS SANZ: Dynamic effects of persistent shocks.

1945 PABLO DE ANDRÉS, RICARDO GIMENO and RUTH MATEOS DE CABO: The gender gap in bank credit access.

1946 IRMA ALONSO and LUIS MOLINA: The SHERLOC: an EWS-based index of vulnerability for emerging economies

1947 GERGELY GANICS, BARBARA ROSSI and TATEVIK SEKHPOSYAN: From Fixed-event to Fixed-horizon Density Forecasts: Obtaining Measures of Multi-horizon Uncertainty from Survey Density Forecasts.

1948 GERGELY GANICS and FLORENS ODENDAHL: Bayesian VAR Forecasts, Survey Information and Structural Change in the Euro Area.

2001 JAVIER ANDRÉS, PABLO BURRIEL and WENYI SHEN: Debt sustainability and fiscal space in a heterogeneous Monetary Union: normal times vs the zero lower bound.

2002 JUAN S. MORA-SANGUINETTI and RICARDO PÉREZ-VALLS: ¿Cómo afecta la complejidad de la regulación a la demografía empresarial? Evidencia para España.

2003 ALEJANDRO BUESA, FRANCISCO JAVIER POBLACIÓN GARCÍA and JAVIER TARANCÓN: Measuring the procyclicality of impairment accounting regimes: a comparison between IFRS 9 and US GAAP.

2004 HENRIQUE S. BASSO and JUAN F. JIMENO: From secular stagnation to robocalypse? Implications of demographic and technological changes

2005 LEONARDO GAMBACORTA, SERGIO MAYORDOMO and JOSÉ MARÍA SERENA: Dollar borrowing, firm-characteristics and FX-hedged funding opportunities.

2006 IRMA ALONSO ÁLVAREZ, VIRGINIA DI NINO and FABRIZIO VENDITTI: Strategic interactions and price dynamics in the global oil market.

2007 JORGE E. GALÁN: The benefits are at the tail: uncovering the impact of macroprudential policy on growth-at-risk.

2008 SVEN BLANK, MATHIAS HOFFMANN and MORITZ A. ROTH: Foreign direct investment and the equity home bias puzzle.

2009 AYMAN EL DAHRAWY SÁNCHEZ-ALBORNOZ and JACOPO TIMINI: Trade agreements and Latin American trade (creation and diversion) and welfare.

2010 ALFREDO GARCÍA-HIERNAUX, MARÍA T. GONZÁLEZ-PÉREZ and DAVID E. GUERRERO: Eurozone prices: a tale of convergence and divergence.

2011 ÁNGEL IVÁN MORENO BERNAL and CARLOS GONZÁLEZ PEDRAZ: Sentiment analysis of the Spanish Financial Stability Report. (There is a Spanish version of this edition with the same number).

2012 MARIAM CAMARERO, MARÍA DOLORES GADEA-RIVAS, ANA GÓMEZ-LOSCOS and CECILIO TAMARIT: External imbalances and recoveries. 
2013 JESÚS FERNÁNDEZ-VILLAVERDE, SAMUEL HURTADO and GALO NUÑO: Financial frictions and the wealth distribution.

2014 RODRIGO BARBONE GONZALEZ, DMITRY KHAMETSHIN, JOSÉ-LUIS PEYDRÓ and ANDREA POLO: Hedger of last resort: evidence from Brazilian FX interventions, local credit, and global financial cycles.

2015 DANILO LEIVA-LEON, GABRIEL PEREZ-QUIROS and EYNO ROTS: Real-time weakness of the global economy: a first assessment of the coronavirus crisis.

2016 JAVIER ANDRÉS, ÓSCAR ARCE, JESÚS FERNÁNDEZ-VILLAVERDE and SAMUEL HURTADO: Deciphering the macroeconomic effects of internal devaluations in a monetary union.

2017 FERNANDO LÓPEZ-VICENTE, JACOPO TIMINI and NICOLA CORTINOVIS: Do trade agreements with labor provisions matter for emerging and developing economies' exports?

2018 EDDIE GERBA and DANILO LEIVA-LEON: Macro-financial interactions in a changing world.

2019 JAIME MARTÍNEZ-MARTÍN and ELENA RUSTICELLI: Keeping track of global trade in real time.

2020 VICTORIA IVASHINA, LUC LAEVEN and ENRIQUE MORAL-BENITO: Loan types and the bank lending channel.

2021 SERGIO MAYORDOMO, NICOLA PAVANINI and EMANUELE TARANTINO: The impact of alternative forms of bank consolidation on credit supply and financial stability.

2022 ALEX ARMAND, PEDRO CARNEIRO, FEDERICO TAGLIATI and YIMING XIA: Can subsidized employment tackle long-term unemployment? Experimental evidence from North Macedonia.

2023 JACOPO TIMINI and FRANCESCA VIANI: A highway across the Atlantic? Trade and welfare effects of the EU-Mercosur agreement.

2024 CORINNA GHIRELLI, JAVIER J. PÉREZ and ALBERTO URTASUN: Economic policy uncertainty in Latin America: measurement using Spanish newspapers and economic spillovers.

2025 MAR DELGADO-TÉLLEZ, ESTHER GORDO, IVÁN KATARYNIUK and JAVIER J. PÉREZ: The decline in public investment: "social dominance" or too-rigid fiscal rules?

2026 ELVIRA PRADES-ILLANES and PATROCINIO TELLO-CASAS: Spanish regions in Global Value Chains: How important? How different?

2027 PABLO AGUILAR, CORINNA GHIRELLI, MATÍAS PACCE and ALBERTO URTASUN: Can news help measure economic sentiment? An application in COVID-19 times.

2028 EDUARDO GUTIÉRREZ, ENRIQUE MORAL-BENITO, DANIEL OTO-PERALÍAS and ROBERTO RAMOS: The spatial distribution of population in Spain: an anomaly in European perspective.

2029 PABLO BURRIEL, CRISTINA CHECHERITA-WESTPHAL, PASCAL JACQUINOT, MATTHIAS SCHÖN and NIKOLAI STÄHLER: Economic consequences of high public debt: evidence from three large scale DSGE models.

2030 BEATRIZ GONZÁLEZ: Macroeconomics, Firm Dynamics and IPOs.

2031 BRINDUSA ANGHEL, NÚRIA RODRÍGUEZ-PLANAS and ANNA SANZ-DE-GALDEANO: Gender Equality and the Math Gender Gap.

\section{BANCODE ESPAÑA}

Eurosistema
Unidad de Servicios Generales

Alcalá, 48 - 28014 Madrid

E-mail: publicaciones@bde.es www.bde.es 